Ocean Sci. Discuss., https://doi.org/10.5194/os-2018-140

Manuscript under review for journal Ocean Sci.

Discussion started: 17 January 2019

(c) Author(s) 2019. CC BY 4.0 License.

Ocean Science

Discussions

(c) (i)

\title{
1 Distribution of Water Masses in the Atlantic Ocean based on 2 GLODAPv2
}

3 Mian Liu $^{1}$, Toste Tanhua ${ }^{1}$

$4{ }^{1}$ GEOMAR Helmholtz Centre for Ocean Research Kiel, Marine Biogeochemistry, Chemical Oceanography, Düsternbrooker 5 Weg 20, 24105 Kiel, Germany

6 Correspondence to: T. Tanhua (ttanhua@geomar.de)

7 
Ocean Sci. Discuss., https://doi.org/10.5194/os-2018-140

Manuscript under review for journal Ocean Sci.

Discussion started: 17 January 2019

(c) Author(s) 2019. CC BY 4.0 License.

8 Abstract: The distribution of the main water masses in the Atlantic Ocean are investigated with the Optimal Multi-

9 Parameter (OMP) method. The properties of the main water masses in the Atlantic Ocean are described in a companion 10 article; here these definitions are used to map out the general distribution of those water masses. Six key properties, 11 including conservative (potential temperature and salinity) and non-conservative (oxygen, silicate, phosphate and nitrate), 12 are incorporated into the OMP analysis to determine the contribution of the water masses in the Atlantic Ocean based on the 13 GLODAP v2 observational data. To facilitate the analysis the Atlantic Ocean is divided into four vertical layers based on 14 potential density. Due to the high seasonal variability in the mixed layer, this layer is excluded from the analysis. Central 15 waters are the main water masses in the upper/central layer, generally featuring high potential temperature and salinity and 16 low nutrient concentrations and are easily distinguished from the intermediate water masses. In the intermediate layer, the 17 Antarctic Intermediate Water (AAIW) from the south can be detected to $\sim 30^{\circ} \mathrm{N}$, whereas the Subarctic Intermediate Water 18 (SAIW), having similarly low salinity to the AAIW flows from the north. Mediterranean Overflow Water (MOW) flows 19 from the Strait of Gibraltar as a high salinity water. NADW dominates the deep and overflow layer both in the North and 20 South Atlantic. In the bottom layer, AABW is the only natural water mass with high silicate signature spreading from the 21 Antarctic to the North Atlantic. Due to the change of water mass properties, in this work we renamed to North East Antarctic 22 Bottom Water NEABW north of the equator. Similarly, the distributions of Labrador Sea Water (LSW), Iceland Scotland 23 Overflow Water (ISOW), and Denmark Strait Overflow Water (DSOW) forms upper and lower portion of NADW, 24 respectively roughly south of the Grand Banks between $\sim 50$ and $66^{\circ} \mathrm{N}$. In the far south the distributions of Circumpolar Deep Water (CDW) and Weddell Sea Bottom Water (WSBW) are of significance to understand the formation of the AABW. 
Ocean Sci. Discuss., https://doi.org/10.5194/os-2018-140

Manuscript under review for journal Ocean Sci.

Discussion started: 17 January 2019

(c) Author(s) 2019. CC BY 4.0 License.

\section{Introduction}

The distribution of properties in the ocean tends to be distributed along bodies of water with similar history, or water masses (Mackas et al., 1987). The properties of water masses further more tend to change along the flow path of a water mass, partly due to biological or chemical changes, i.e. non-conservative behavior of properties, and due to mixing with surrounding water masses (Hinrichsen and Tomczak, 1993; Klein and Tomczak, 1994). Knowledge of the distribution and variation of water masses is of fundamental importance in oceanography, particularly for biogeochemical and biological applications where the transformation of properties over time can be successfully viewed in the water mass frame-work. For instance, the process of deep water formation from near surface waters enable the effects of air-sea gas exchange to penetrate the deep waters. In the North Atlantic deep water formation transports anthropogenic carbon and oxygen from the surface to the deep ocean (e.g. Garcia-Ibanez et al., 2015). Furthermore, the interactions of water masses influence the distribution of biologically important elements, such as oxygen, carbon and nutrients (e.g. Karstensen et al., 2008). All of these studies show that the study of water masses plays not only an important role in physical oceanography, but also irreplaceable role in biogeochemistry.

With an increasing number of publications focusing on water mass characterization on a global (e.g. Stramma and England, 1999) and regional scale (e.g. Carracedo et al., 2016; Talley, 1996), differences in research goals and areas has resulted in different definitions and names of water masses by researchers. For example, in a study focusing on T-S distribution, shallow water masses are named as Mode Water due to their linear, T-S relationship (McCartney and Talley, 1982). But other works referred the same water masses as Central Water, since the authors focused more on the distribution and transport of mass and chemical constituents (Garcia-Ibanez et al., 2015). Here we follow the approach by Garcia-Ibanez et al. (2015) and utilize the definitions of water masses that we present in a companion paper to map out the general distribution of water masses in the Atlantic Ocean.

In the Atlantic Ocean, warm upper/central waters are generally transported northward into the high latitude North Atlantic, where the dense and cold deep water is formed, and subsequently sinks and spreads southward across the equator into the South Atlantic (Fyfe et al., 2007).

Consistent with the work in our companion paper (Liu and Tanhua, 2019), we divide the water column into four vertical layers based on potential density $\left(\sigma_{\theta}\right)$. Water masses in the upper/central layer $\left(\sigma_{\theta}<27 \mathrm{~kg} / \mathrm{m}^{3}\right)$ origin from seawater that subduct into the thermocline during winter time. Four water masses are located in this layer: the East North Atlantic Central Water (ENACW), West North Atlantic Central Water (WNACW), East South Atlantic Central Water (ESACW) and West South Atlantic Central Water (WSACW). In the intermediate layer $\left(\sigma_{\theta}=27-27.7 \mathrm{~kg} / \mathrm{m}^{3}\right)$, three water masses are identified. In the South Atlantic, Antarctic Intermediate Water (AAIW) originates from the surface (upper 200m) in the region north of Antarctic Circumpolar Current (ACC) and east of Drake Passage (Alvarez et al., 2014; Talley, 1996). In the North Atlantic, 
Ocean Sci. Discuss., https://doi.org/10.5194/os-2018-140

Manuscript under review for journal Ocean Sci.

Discussion started: 17 January 2019

(C) Author(s) 2019. CC BY 4.0 License.

Subarctic Intermediate Water (SAIW) originates from surface in the western boundary of Subpolar Gyre and spreads southward along the Labrador Current (Pickart et al., 1997). In the east, Mediterranean Overflow Water (MOW) flows through the Strait of Gibraltar with a feature of high salinity. North Atlantic Deep Water (NADW) is the dominant water mass in the deep and overflow layer $\left(\sigma_{\theta}=27.7-27.88 \mathrm{~kg} / \mathrm{m}^{3}\right)$. This water mass is formed in the high latitude North Atlantic, with relatively high potential density due to the low potential temperature and high salinity. We further divide the NADW into upper and lower portions by different potential density and origins. Labrador Sea Water (LSW) is the origin of upper version of NADW (uNADW) whereas Iceland-Scotland Overflow Water (ISOW) and Denmark Strait Overflow Water (DSOW) are origins of lower NADW. Antarctic Bottom Water (AABW) is the main water mass in the bottom layer $\left(\sigma_{\theta}>\right.$ $27.88 \mathrm{~kg} / \mathrm{m}^{3}$ ). This water mass is a mixed product between Weddell Sea Bottom Water (WSBW) and Circumpolar Deep Water (CDW) (van Heuven et al., 2011; Weiss et al., 1979). In regions north of the equator we define AABW as a new water mass, the Northeast Atlantic Bottom Water (NEABW).

\section{Data and Methods}

There are some key features of the distribution of properties that are well known, but never the less are helpful in understanding the distribution of water masses in the Atlantic Ocean. We use a meridional section across the Atlantic Ocean to illustrate this, the WOCE/GO-SHIP A16 section as occupied by cruise 33RO20130803 (North Atlantic) \& 33RO20131223 (South Atlantic), Figure 1. In the upper layer, high temperatures, salinities and low nutrients, especially nitrate can be seen on the section plots. The above characteristics are consistent with the properties of central water masses. The intermediate layer is characterized by low salinity and high nitrate and silicate in the South Atlantic. According to this feature, the location of AAIW can be initially determined. And relative high salinity distributes around $40^{\circ} \mathrm{N}$ is the signal of MOW. High oxygen in the north helps to label SAIW. Relative higher salinity and oxygen but lower nutrients (silicate and nitrate) are important signals of water masses in deep and overflow layer (upper and lower NADW) to distinguish from intermediate and bottom waters. High silicate is one significant property to identify AABW in bottom layer. Also this layer has the lowest potential temperature. In the north hemisphere, there is a sudden reduction of silicate compared with south of equator. This is the reason that a new water mass, NEABW, is defined in this region.

\subsection{The GLODAPv2 dataset}

Marine surveys from different countries are actively organized and coordinated since late 1950s, after the establishment of the Scientific Committee for Marine Research (SCOR) in 1957 and the Intergovernmental Oceanographic Commission (IOC) in 1960. And meanwhile, academic exchanges between world countries and organizations became frequent and popular. WOCE (the World Ocean Circulation Experiment), JGOFS (Joint Global Ocean Flux Study) and OACES (Ocean Atmosphere Carbon Exchange Study) are the three most typical representatives after entering 1990s. However, these programs are initiated by different countries and with their respective aims and goals. Hence, coordination and collaboration between the countries are necessary and beneficial. GLODAP (Global Ocean Data Analysis Project) is a data product that 
Ocean Sci. Discuss., https://doi.org/10.5194/os-2018-140

Manuscript under review for journal Ocean Sci.

Discussion started: 17 January 2019

(c) Author(s) 2019. CC BY 4.0 License.

Discussions

(c) (i)

came into being in this context. In addition to create a global dataset based on above programs, the goals of GLODAP include also to describe distribution and biogeochemical properties in the global ocean and to make data publicly available (Key et al., 2004). The GLODAP dataset shows a good start for global data sharing however the shortcomings also cannot be ignored. From the spatial scale, few data in high latitude region, north of $60{ }^{\circ} \mathrm{N}$ or in the Arctic region, are collected in this dataset, and meanwhile, data from Mediterranean Sea are also not included. In the term of time, GLODAPv1.1 contains data only until 1999. The updated and expanded dataset GLODAPv2 successfully made up for the above disadvantages (Lauvset et al., 2016). In addition to the integration of two other datasets, CARINA (CARbon dioxide IN the Atlantic Ocean, Key et al., 2010) and PACIFICA (PACIFic ocean Interior Carbon, Ishii et al., 2011), GLODAPv2 also includes an 168 additional independent cruises those never been collected by any datasets. Thus GLODAPv2 is a dataset that includes relatively complete data and with an almost global coverage, and also include a mapped product.

\subsection{OMP Analysis}

For the water mass analysis we used in total 6 key properties, including two conservative (potential temperature and salinity) and four non-conservative (oxygen, silicate, phosphate and nitrate) properties to define the Source Water Types (SWTs) as origins of water masses, see the companion study (Liu and Tanhua 2019 for details). Based on the above observational data, it is obviously not enough to make accurate estimation of the distribution of the water masses only by displaying key properties. In order to determine the distribution of water masses exactly, we have to resort to more accurate mathematical calculations. Since the first publication of global distributions of water masses (Sverdrup, 1942), early studies on water masses are mainly based on potential temperature and salinity. Emery and Meincke made on summary and review on this kind of analysis in 1986 (Emery and Meincke, 1986). The limitation of this method is that distribution of more (more than three) water masses cannot be calculated at the same time with only these two parameters. So during the same time as the development of this theory, physical and chemical oceanographers also tried to add more parameters to the calculation and the Optimum Multi-parameter (OMP) analysis is one of the typical products.

Base on above results, Tomczak (1981) extended the analysis into more than three water masses by adding more parameters/water properties (such as phosphate and silicate) and solving the equations of linear mixing without assumptions. In Tomczak and Large (1989), this method was successfully applied to the analysis of mixing in the thermocline in Eastern Indian Ocean. As a summary and practical use of the above results, the Optimal Multivariable Parameter (OMP) analysis was developed and successfully applied in the analysis of water masses in specific regions (e.g. Karstensen and Tomczak, 1997, 1998a). Parameters (6 key water properties in our study) from the water samples are extracted and compared with SWTs of each water masses to identify their composition structure and percentage in detail.

Before we start the calculation of OMP analysis, some basic definitions of SWTs need to be reiterated again. SWTs are the origin water masses in their formation area and carry their own properties (Poole and Tomczak, 1999). During transport and 
Ocean Sci. Discuss., https://doi.org/10.5194/os-2018-140

Manuscript under review for journal Ocean Sci.

Discussion started: 17 January 2019

(c) Author(s) 2019. CC BY 4.0 License.

mixing on the pathway, the total amount of water properties remains constant. In a mixed product of two water masses, contribution from each SWT can be calculated by using a linear set of mixing equations, if we know one water property (such as salinity) in this mixed product and both SWTs. But only one property/parameter becomes insufficient if there are three or more water masses mix together. As a result, we can calculate the percentages of each water mass in a final mixed product with more water masses, with the essential prerequisite that the number of water masses not larger than the number of variables plus one.

The theory and formulas in the OMP analysis are described in detail in Tomczak and Large (1989) and the website http://omp.geomar.de/. Here we make a brief introduction to the OMP calculation that relates directly to our research, for more details see the references above. OMP calculation is based on a simple model of linear mixing, assuming that all key properties of water masses are affected by the same mixing process, and then to determine the distribution and of water masses through the following linear equations.

\section{$\mathbf{G x}-\mathbf{d}=\mathbf{R}$}

Where $\mathbf{G}$ is a parameter matrix of defined source water types (6 key properties in this study), $\mathbf{x}$ is a vector containing the relative contributions of the water types to the sample (i.e. solution vector of the source water type fractions), $\mathbf{d}$ is a data vector of water samples (observational data from GLODAPv2 in this study) and $\mathbf{R}$ is a vector of residual. The solution is to find out the minimum the residual (R) with linear fit of parameters (key properties) for each data point with a non-negative values.

Prerequisites (or restrictions) for using classic OMP is that source water types are defined closely enough to the observational water samples with short transport times, so that the mixing can be assumed not influenced by biogeochemical processes (i.e. consider all the parameters as quasi-conservative). Obviously, this prerequisite does not apply to our investigation for the entire Atlantic scale, so we use the extended OMP analysis instead. The way of considering biogeochemical processes is to convert non-conservative parameters (phosphate and nitrate) into conservative parameters by introducing the "preformed" nutrients PO and NO, where PO and NO show the concentrations of Phosphate and Nitrate in sea water by considering the consumption of dissolved Oxygen from respiration (in other words, the alteration due to respiration is eliminated) (Broecker, 1974; Karstensen and Tomczak, 1998b).

\subsection{OMP runs in this study}

As mentioned in the companion paper (Liu and Tanhua, 2019) Source Water Types (SWTs) are the origin form of each water mass in the formation area and we grasp the properties of main SWTs in the Atlantic Ocean. In this study, we show the distributions of water masses in Atlantic Ocean after formations based on OMP analysis. The key properties of SWTs are used in OMP analysis as the basis to determining the distributions of water masses. 
Ocean Sci. Discuss., https://doi.org/10.5194/os-2018-140

Manuscript under review for journal Ocean Sci.

Discussion started: 17 January 2019

(c) Author(s) 2019. CC BY 4.0 License.

Discussions

(c) (i)

154

155

156

157

158

159

160

161

162

163

164

165

166

167

168

169

170

171

172

173

174

175

176

177

178

179

180

181

182

183

184

185

In order to map all the distribution of water masses in the Atlantic we analyzed all the GLODAPv2 data in the Atlantic Ocean with OMP method by using 6 key properties from each water sample (potential temperature, salinity, oxygen, silicate, phosphate and nitrate). However some of these variables co-vary to some extent, in particular phosphate and nitrate, so that we have to control that in each OMP run we should have less than 6 water masses. Some regional factors should also be considered, as some water masses mix and new SWTs are formed during their mixing process. For example, LSW, ISOW and DSOW mix in the North Atlantic after leaving their formation area, as a result, SWTs of upper and lower NADW are formed. Here we specify some 'mixing regions' for these water masses. Between 40 and $60{ }^{\circ} \mathrm{N}$, we define such a 'mixing region', since all the five water masses including already formed LSW, ISOW and DSOW and newly formed upper and lower NADW simultaneously exist. So in this region, key properties from all these five SWTs are used simultaneously in OMP runs. In south of $40^{\circ} \mathrm{N}$, only upper and lower NADW are used while north of $60^{\circ} \mathrm{N}$, only LSW, ISOW and DSOW are used. A similar situation exists in the South Atlantic where we consider south of 50 'S as another 'mixing region', since a new SWT of AABW is formed here due to the mixing of CDW and WSBW. So in this region, key properties from all the three SWTs are used in the OMP runs while in north of $50^{\circ} \mathrm{S}$, only AABW is used.

Consolidate the above reasons, and also consider the distribution of all the water masses, all the data in the Atlantic Ocean are divided into four, almost vertical, layers by potential density, since all the water masses distribute within their core layer and only mix with neighboring water masses at the boundary of each layer. In horizontal direction, Atlantic Ocean is manually divided into several horizontal sections in order to remove water masses that are not likely to appear in the area to avoid excessive (more than 6) water masses in each OMP run. The central layer is divided into two sections by $35^{\circ} \mathrm{N}$ to distinguish SAIW and AAIW, which has similar properties. In the intermediate and deep layer, Atlantic Ocean is divided into three sections. The region north of $60^{\circ} \mathrm{N}$ contains the LSW, ISOW and DSOW. From 40 to $60{ }^{\circ} \mathrm{N}$ is defined as mixing region. LSW, ISOW, DSOW mix with each other and finally form upper and lower NADW. As a result, all the five SWTs should be contained in one OMP runs in this section. And the third part, from $50^{\circ} \mathrm{S}$ to $40^{\circ} \mathrm{N}$, only upper and lower NADW are considered. In high latitude region in South Atlantic, mixing region of CDW and WSBW is defined as south of $50^{\circ} \mathrm{S}$. In this mixing region, CDW, WSBW mix and AABW is formed, but no horizontal layer division in this area because the difference of density is not obvious. From north of $50^{\circ} \mathrm{S}$ only AABW are used in OMP runs until equator. In addition, for relative special long transport water masses those across the equator, AAIW upper and lower NADW, we do not subject to restrictions of equator.

This way we end up with a set of 13 different OMPs that are used for estimating the fraction of water masses in each water sample. The density and the latitude of the water sample is used to determine which IMP should be applied, Table 1. Note that all water masses are present in more than one OMP so that reasonable smooth (i.e. realistic) transitions between the different OMPs can be realized. However, it is unavoidable that there will occasionally be step-like features across the vertical and horizontal boundaries defined in Table 1. 
Ocean Sci. Discuss., https://doi.org/10.5194/os-2018-140

Manuscript under review for journal Ocean Sci.

Discussion started: 17 January 2019

(c) Author(s) 2019. CC BY 4.0 License.

Discussions

(c) $($ P)

186

187

188

189

190

191

192

193

194

195

196

197

198

199

200

201

202

203

204

205

206

207

208

209

210

211

212

213

214

215

\section{Result: Distribution of water masses based on GLODAPv2}

In this section, the horizontal and vertical distributions of the main water masses are displayed in different density layers. On the maps of horizontal view, water mass fractions are plotted at each station with the interpolated format at their core densities. In order to avoid large interpolation errors, a station is considered as without data and plotted as grey rather than colored dots if there is no data within $\pm 0.1 \mathrm{~kg} / \mathrm{m}^{3}$ from core density.

To exemplify the vertical distribution of the water masses we are also display sections from representative cruises. For this we use 5 selected WOCE/GO-SHIP cruises that together provide a reasonable representation of the Atlantic Ocean, as shown in Figure 2. These are the A16 cruise (Expocodes: 33RO20130803 \& 33RO20131223) that is a meridional overview of all the main water masses in the Atlantic Ocean, and that was also used for the distribution of the properties in Figure 1. The A05 (Expocode: 74AB20050501) and A10 (Expocode: 33RO20110906) sections displays the zonal distribution of the water masses in the North (A05) and South (A10) Atlantic separately. The A25 (Expocode: 06MM20060523) section is located at a relative higher latitude region compared to the A05 section and better represent the deep and overflow waters in particular. From this cruise, we focus on the investigation of LSW, ISOW and DSOW, with the purpose to show origin of upper and lower NADW. The SR04 (Expocode: 06AQ20101128) on the other hand is a section in the Antarctic region near Weddell Sea with certain significance for the origin and formation of AABW. For each figure with horizontal distribution we also display a map with a cartoon of the main currents in that density layer and with the main formation region of each water mass indicated as striped boxes.

In this section horizontal and vertical distribution of all water masses discussed and defined in the companion paper (Liu and Tanhua, 2019) are displayed on maps and sections respectively. We start with the Upper Layer and work our way down the water column. In the Upper Layer $\left(\sigma_{\theta}<27 \mathrm{~kg} / \mathrm{m}^{3}\right.$ and mostly with depths above $\left.\sim 500-1000 \mathrm{~m}\right)$, central waters are the dominate water masses in this layer, where we define four SWTs, ENACW, WNACW, ESACW and WSACW (see table 3 in the companion paper, Liu and Tanhua, 2019 for definitions). Below the Upper Layer resides the Intermediate Layer $\left(\sigma_{\theta}\right.$ between 27 and $27.7 \mathrm{~kg} / \mathrm{m}^{3}$ and mostly with depths between $\sim 1000$ and 2000m). In this layer, we have the following SWTs; SAIW from the north AAIW from the south and MOW from the east. The Deep Layer resides from $\sim 2000$ to $4000 \mathrm{~m}$ and $\sigma_{\theta}$ between 27.7 and $27.88 \mathrm{~kg} / \mathrm{m}^{3}$. The upper and lower NADW are two main SWTs in mid and low latitude region in this layer. Their origin, LSW, ISOW and DSOW will also be investigated in relative high latitude region. Both bottom waters are located in the Bottom Layer below $4000 \mathrm{~m}$ with $\sigma_{\theta}>27.88 \mathrm{~kg} / \mathrm{m}^{3}$. AABW and NEABW are two main water masses in this layer and have similar properties, especially high silicate. Traced back to the source, NEABW is a branch from AABW after passing the equator. After spanning most Atlantic there is a sharp reduction of silicate concentration this is the reason why we define a new SWT of NEABW. 
Ocean Sci. Discuss., https://doi.org/10.5194/os-2018-140

Manuscript under review for journal Ocean Sci.

Discussion started: 17 January 2019

(c) Author(s) 2019. CC BY 4.0 License.

\subsection{The Upper Layer: ENACW, WNCAW, ESACW and WSCAW}

The horizontal distributions of four main water masses in the Upper Layer are shown on the maps in Figure 3. In general, eastern central waters, both for the northern and southern variation, have relative higher potential density and are located at deeper depth (i.e. higher density) compared with western central waters. In spatially distribution, the East North Atlantic Central Water (ENACW) is mainly located in the north east part of North Atlantic, near the formation area. The ENACW is formed during winter subduction in the seas west of Iberian Peninsula and drifts to the south along the south branch of the North Atlantic Current (McCartney and Talley, 1982) and mainly locates in north east part of North Atlantic, near the formation area (Garcia-Ibanez et al., 2015; Talley and Raymer, 1982). The WNACW, which is formed at the south flank of the Gulf Stream (Klein and Hogg, 1996), spreads along the North Atlantic Current and distributes in east-west band between $\sim 10^{\circ} \mathrm{N}$ and $40^{\circ} \mathrm{N}$.

East South Atlantic Central Water (ESACW) distributes all over most South Atlantic and with lower percentages $(\sim 30$-$40 \%$ ) can also be found in the tropical and subtropical north Atlantic below (at higher densities) than the West North Atlantic Central Water (WNACW). WNACW is located in north tropical and subtropical North Atlantic, where this water mass is formed. West South Atlantic Central Water (WSACW) dominates the upper layer of South Atlantic, resides over ESACW and can also be seen above ENACW in the North Atlantic. In the South Atlantic, our results are similar to those of (Kirchner et al., 2009) that found that the WSACW and ESACW spread all over the South Atlantic, eastward along South Atlantic Current, and then northwest along the Benguela Current and South Equator Current, and finally southward along Brazilian Current. In general, both WSACW and ESACW dominate the central/upper layer in South Atlantic and across the equator until $\sim 10^{\circ} \mathrm{N}$.

The WSACW is formed in the region near the South America coast between 30 and $45{ }^{\circ} \mathrm{S}$, where surface South Atlantic Current brings central water to the east (Kuhlbrodt et al., 2007). Formation of ESACW takes place in the eastern South Atlantic Ocean close to the area southwest of South Africa (Deruijter, 1982; Lutjeharms and van Ballegooyen, 1988) and spreads to the north along the Benguela Current (Peterson and Stramma, 1991).

From the A16 and A05 sections the meridional and zonal distribution of WNACW and ENACW, the both dominating central water masses in North Atlantic, can be seen. The vertical distribution shows that the WNACW is located at lower densities compared to the ENACW. In the zonal A05 section the difference between east and west of the Mid-Atlantic-Ridge (MAR) is obvious; west of the MAR WNACW dominates the upper layer. Both thickness and percentage are significantly larger than east, while the situation in east of MAR is the opposite, due to their distance from respective formation areas. ENACW is located at the upper $\sim 500 \mathrm{~m}-1000 \mathrm{~m}$ below WNACW and over SAIW and MOW.

The vertical distribution of WSACW and ESACW based on A16 and A10 sections has similarities to the north central waters where the western variety is located at lower densities compared to the eastern variety. The distribution of WSACW and ESACW can be clearly seen by Figure 4 including their transports to the north that can be clearly seen by the A16 section. In 
Ocean Sci. Discuss., https://doi.org/10.5194/os-2018-140

Manuscript under review for journal Ocean Sci.

Discussion started: 17 January 2019

(c) Author(s) 2019. CC BY 4.0 License.

Discussions

(c) (i)

contrast to the north Atlantic the difference between east and west of the MAR, as seen in the A10 section, is not clear compared with the A05 section for the North Atlantic.

\subsection{The Intermediate Layer: AAIW, SAIW and MOW}

In the intermediate layer $\left(\sigma_{\theta}\right.$ between 27 and $\left.27.7 \mathrm{~kg} / \mathrm{m}^{3}\right)$ three water masses can be considered as dominating. Two of them, the Subarctic Intermediate Water (SAIW) and the Mediterranean Overflow Water (MOW), show Northwest-Southeast distinction in their distribution in the North Atlantic although with similar densities. The SAIW is located in north of $40{ }^{\circ} \mathrm{N}$ with higher percentages in the western part while the MOW is mainly distributed in the region east of the Mid-AtlanticRidge, which is consistent with results from (Read, 2000). The third water mass, the AAIW, has s southern origin and is found at lighter densities, Figure 5

In the South Atlantic, AAIW is the only water mass that origins from the south hemisphere in the Intermediate Layer and has the lowest potential density (main core with potential density $27.2 \mathrm{~kg} / \mathrm{m}^{3}$ ) of these three water masses. The AAIW originates from the surface layer (upper 200m) north of the Antarctic Circumpolar Current (ACC) and east of Drake Passage (Alvarez et al., 2014; McCartney, 1982). Most AAIW is formed in the region south of $40^{\circ} \mathrm{S}$ where it sinks and spreads to the north at pressures between $\sim 1000$ and $2000 \mathrm{db}$ at potential densities between 27.0 and $27.7 \mathrm{~kg} / \mathrm{m}^{3}$ (Talley, 1996).

On the map, the spread of AAIW covers most of the Atlantic Ocean until $\sim 40{ }^{\circ} \mathrm{N}$ and the percentage shows a decrease trend to the north (Kirchner et al., 2009). The AAIW shows a general distribution within the intermediate layer based on potential density $\left(\sigma_{\theta}\right)$ between 27.0 and $27.7 \mathrm{~kg} / \mathrm{m}^{3}$, Figure 7 . At $\sim 40{ }^{\circ} \mathrm{S}$, upper NADW injects into the space between AAIW and AABW (Figure 12) and all the three water masses mix with each other in this area. From the observations on the meridional A16 section, the AAIW spreads northward after the leaving the formation area, across the equator and further north until 40 ${ }^{\circ} \mathrm{N}$, where it meets MOW and SAIW. The upper boundary between AAIW and central waters (ENACW and ESACW) are mostly along the potential density line $\sigma_{\theta}=27.7 \mathrm{~kg} / \mathrm{m}^{3}$. Based on A10 section the zonal distribution of AAIW is consistent with the results A16 section and is the dominating intermediate water mass in the South Atlantic.

The SAIW, as one of the main intermediate water mass in North Atlantic, originates from the surface layer of the western boundary of the North Atlantic Subpolar Gyre, sinks and spreads along the Labrador Current, crossing the MAR in the region north of $40^{\circ} \mathrm{N}$ (Lazier and Wright, 1993; Pickart et al., 1997).

From the A16 section, only some light trace of SAIW in the north can be found since this cruise in 2013 was distance away from the formation area of SAIW in northwest Atlantic. On the zonal A05 section SAIW is a dominating intermediate water mass above the LSW, Figure 6, particularly in the western basin since SAIW originates in the west. 
Ocean Sci. Discuss., https://doi.org/10.5194/os-2018-140

Manuscript under review for journal Ocean Sci.

Discussion started: 17 January 2019

(c) Author(s) 2019. CC BY 4.0 License.

Discussions

(c) (i)

MOW is another main intermediate water mass that is present in the North Atlantic. This water mass overflows from Strait of Gibraltar at $\sim 40^{\circ} \mathrm{N}$ and spreads in two branches to the north and the west (Price et al., 1993). The MOW originates from the east in the Gulf of Cadiz where Mediterranean Water exits the Strait of Gibraltar as a deep current and then turns into two branches after leaving the formation area near. One branch spreads to the north into the West European Basin until $\sim 50^{\circ} \mathrm{N}$, the other branch spreads to the west until, and past, the Mid-Atlantic-Ridge.

From the A16 section the MOW can be found between $\sim 20$ and $50^{\circ} \mathrm{N}$, surrounded by ENACW from the top, SAIW from the north, AAIW from the south and upper NADW from bottom. The observations from the A05 section shows that the MOW flows from the east and spreads westwards until passing the MAR. East of the MAR the trace of MOW is clear, particularly in the region close the Strait of Gibraltar.

\subsection{The Deep and Overflow Layer: upper and lower NADW, LSW, ISOW and DSOW}

As one of the main components of the thermohaline circulation in Atlantic Ocean, formation and distribution of North Atlantic Deep Water (NADW) is the focus of several studies. NADW is the only main water mass that dominates the deep and overflow layer with potential density $\left(\sigma_{\theta}\right)$ between 27.70 and $27.88 \mathrm{~kg} / \mathrm{m}^{3}$ and can be divided into two portions (upper and lower) due to different properties and origins (Smethie and Fine, 2001). In this section, both portions, together with their origins, are analyzed as independent water masses separately.

In the deep and overflow layer three water masses dominate the region north of $40^{\circ} \mathrm{N}$, Figure 7: Labrador Sea Water (LSW), Iceland-Scotland Overflow Water (ISOW) and Denmark Strait Overflow Water (DSOW). They are considered as the origin of North Atlantic Deep Water (NADW). In the region south from $40^{\circ} \mathrm{N}$ the upper and lower NADW, considered as products from the original three overflow water masses, can be found all over the Atlantic Ocean in the deep and overflow layer. The Labrador Sea Water (LSW) is formed in the region of Labrador Sea by deep convection during winter (Clarke and Gascard, 1983), and is typically found at mid-depth with $\sigma_{\theta}=\sim 27.77 \mathrm{~kg} / \mathrm{m}^{3}$. This water mass was noted by (Wüst and Defant, 1936) due to its salinity minimum and later defined and named by Smith et al. (1937). Since then, with the deepening of research on this water mass, the character was discovered as a contribution to the driving mechanism of northward heat transport in the Atlantic Meridional Overturning Circulation (AMOC) (Rhein et al., 2011). In the specific study on this water mass, LSW is divided into two units, 'upper' and 'classic', based on the differences in temperature and salinity (Kieke et al., 2007; Kieke et al., 2006). In the large scale as throughout the whole Atlantic Ocean, LSW is still treated as a unified water mass and considered as the main origin of upper NADW (Elliot et al., 2002; Talley and Mccartney, 1982). In the general scale, LSW distributes in the western part of the North Atlantic in Labrador Sea and Irminger Sea region and the distribution is influenced by the Gulf Stream, the Labrador Current and the North Atlantic Current (Elliot et al., 2002; Talley and Mccartney, 1982). 
Ocean Sci. Discuss., https://doi.org/10.5194/os-2018-140

Manuscript under review for journal Ocean Sci.

Discussion started: 17 January 2019

(c) Author(s) 2019. CC BY 4.0 License.

Seen from the aerial view of the analysis results to the whole GLODAPv2 dataset, Figure 8, LSW mainly distributes in the Northwest Atlantic north $40^{\circ} \mathrm{N}$ near the Labrador Sea and Irminger Basin with core at $\sigma_{\theta}=\sim 27.77 \mathrm{~kg} / \mathrm{m}^{3}$. In terms of vertical distribution, A25 cruise (Expocode: 06MM20060523) shows that LSW dominates the depth between 500 and $2000 \mathrm{~m}$, and meanwhile, the fraction decreases with the spatial change to the east (direction to Iberian Peninsula) thus far away from the formation area (Greenland). This distribution is basically consistent with historical literatures. After southward transport with Labrador Current, LSW spreads eastward with Gulf Stream and North Atlantic Current until it meets MOW. In general, LSW is the dominate mid-depth water mass in the region north of $40{ }^{\circ} \mathrm{N}$ in Northwest Atlantic.

The Iceland-Scotland Overflow Water (ISOW) and Denmark Strait Overflow Water (DSOW), as original water masses that contribute to the formation of the lower NADW (Read, 2000), are located in the west and east part of North Atlantic (north of $40^{\circ} \mathrm{N}$ ) respectively with the main core near $\sigma_{\theta}=27.88 \mathrm{~kg} / \mathrm{m} 3$. Both ISOW and DSOW are formed by water masses from the Arctic Ocean and the Nordic Seas those reach the North Atlantic Ocean (Lacan and Jeandel, 2004; Tanhua et al., 2005). As an indispensable link of the thermohaline circulation, the southward outflow of ISOW and DSOW to the Atlantic Ocean plays an important role, as well as LSW, in the deep-water component of the AMOC and has certain a certain impact on the European and even the global climate.

In general, ISOW is formed in the regions of Greenland, Iceland and Norwegian Seas, outflows southward in the west of Iceland, across the Faeroe Bank Channel into the eastern part of North Atlantic Ocean (Kissel et al., 1997; Swift, 1984). From a more specific perspective, ISOW has two branches. One branch passes near the Charlie-Gibbs Fracture Zone (CGFZ) and flow into Irminger basin at densities above the DSOW. The other branch goes southward into the West European Basin and meets the Northeast Atlantic Bottom Water (NEABW) (Garcia-Ibanez et al., 2015).

Consistent with literatures, the top view distribution from map shows ISOW mainly distributes in the Northeast Atlantic north $40^{\circ} \mathrm{N}$ between Iceland and Iberian Peninsula with core at $\sigma_{\theta}=\sim 27.88 \mathrm{~kg} / \mathrm{m}^{3}$. In terms of vertical distribution, the A25 section shows that ISOW outflows at east of Iceland across Iceland-Faroe Ridge with core at depth between 2000 and $3000 \mathrm{~m}$. In west of Iceland, ISOW can also be found in the Denmark Strait, where core of DSOW is located, with low fraction.

DSOW is the water mass that overflows through the Denmark Strait in west of Iceland and into Irminger Basin and Labrador Sea with $\sigma_{\theta}=\sim 27.88 \mathrm{~kg} / \mathrm{m}^{3}$ (Tanhua et al., 2005). This overflow water mass is considered as the coldest and densest component of the sea water in the Northwest Atlantic Ocean and constitute a significant part of the southward flowing NADW (Swift, 1980). Compositions of DSOW can be traced to many surrounding water masses. Besides Arctic Intermediate Water (AIW), Re-circulating Atlantic Water (RAW), Polar Surface Water (PSW) and Arctic Atlantic Water (AAW) are all considered to be parts of the source (Clarke et al., 1990; Smethie Jr, 1993; Swift, 1980; Tanhua et al., 2005). Rudels et al. (2002) noted the contribution from East Greenland Current (EGC) to the DSOW, EGC that brings Arctic Water 
Ocean Sci. Discuss., https://doi.org/10.5194/os-2018-140

Manuscript under review for journal Ocean Sci.

Discussion started: 17 January 2019

(c) Author(s) 2019. CC BY 4.0 License.

Discussions

(c) $($ P)

in deep layer through the Fram Strait into the Greenland Sea is known as the main mechanism of forming DSOW and this provided us a theoretical basis for determining the distribution of DSOW.

According to the OMP calculations, and also referring to the above literature, the following conclusions about DSOW can be drawn. In the horizontal direction, map distribution shows DSOW mainly distributes along the drainage area of EGC with $\sigma_{\theta}$ $=\sim 27.88 \mathrm{~kg} / \mathrm{m}^{3}$. DSOW starts from the Greenland Sea, southward flows into the Irminger Sea along EGC and then westward into Labrador Sea. The vertical distribution based on the A25 section shows that DSOW overflows through the GreenlandScotland Ridge close proximity to the continental slope with core at depth between $\sim 2500$ and $3000 \mathrm{~m}$. Compared with ISOW, pathway of DSOW is relative narrow and limited within the eastern bottom in the Irminger Basin.

Main cores of ISOW and DSOW can be seen in both sides of Iceland separately below LSW. ISOW distributes all over the region between Greenland and Iberian Peninsula. After passing the Iceland, ISOW and DSOW convergence into one share and spread further southward. All the three water masses, LSW ISOW and DSOW, origin from the North Atlantic region, spread southward and finally become the dominate water masses in deep and overflow layer. Considering the change of properties during the pathway, especially the final product of mixing compared with original ISOW and DSOW, also in order to comply with the needs of large-scale distribution in Atlantic Ocean and without paying too much attention to these details, two new water masses, upper and lower NADW based on SWTs in the companion paper (Liu and Tanhua, 2019), are adopted in the main Atlantic region south of $40^{\circ} \mathrm{N}$, whereas LSW ISOW and DSOW are not used in the OMP analysis and replaced upper and lower NADW.

After passing $40^{\circ} \mathrm{N}$, upper and lower NADW, considered as independent water masses, continue to spread until $\sim 50{ }^{\circ} \mathrm{S}$ and dominate the most Atlantic Ocean in this layer. During the process to the south, NADW is transported along Deep West Boundary Current (DWBC) and also eastward with eddies (Lozier, 2012).

The OMP analysis shows that the upper and lower NADW are the main water masses in Deep and Overflow Layer, Figure 9. As the productions and considered as independent water masses, upper NADW distributes at a relative shallow pressure, while lower NADW with higher pressure close to their original water masses. After molding, upper and lower NADW are formed and spread southward with DWBC along the continental slope also spreads eastward and cover mostly all over the Atlantic Ocean in this layer due to eddies during the pathway (Lozier, 2012).

In horizontal scale, the map view shows that upper NADW covers the most area of deep and overflow layer, while lower NADW is found with higher fractions in the west region near the Deep Western Boundary Current (DWBC), especially in South Atlantic. In the vertical scale based on observation from meridional (A16) and zonal (A05 and A10) cruises, relative thicker lower NADW than upper NADW are discovered. Upper NADW, due to lower potential density, lies over lower NADW during the whole way to the south with their boundary at $\sim 2000 \mathrm{~m}$ depth. The boundary between upper NADW and 
Ocean Sci. Discuss., https://doi.org/10.5194/os-2018-140

Manuscript under review for journal Ocean Sci.

Discussion started: 17 January 2019

(c) Author(s) 2019. CC BY 4.0 License.

Discussions

(c) (i)

intermediate water masses, AAIW and SAIW, are almost along our definition line $\left(\sigma_{\theta}=27.7 \mathrm{~kg} / \mathrm{m}^{3}\right)$. AABW is the only bottom water mass that contacts with upper NADW. In the region south of $40^{\circ} \mathrm{S}$, upper NADW is deflected up after it meets AABW and high mixing happens in this region due to ACC. Lower NADW is seen south to $\sim 40{ }^{\circ} \mathrm{S}$ where it meets AABW.

\subsection{The Bottom Layer: AABW and NEABW}

AABW and NEABW dominate the bottom layer $\left(\sigma_{\theta}>27.88 \mathrm{~kg} / \mathrm{m}^{3}\right)$. In fact, both water masses have the same origin but distinguished by defining a new SWT as NEABW due to the sharp reduction of silicate, which is an important signal to label bottom water masses, after passing the equator. From aerial view of the maps, Figure 10, AABW and NEABW cover the most bottom area of South and North Atlantic respectively.

The AABW is formed in the Weddell Sea region south of the Antarctic Circumpolar Current (ACC). After leaving the formation area, AABW sinks to the bottom due to the high density during the way north. After passing the ACC, AABW meets NADW and they have some water exchange from $50^{\circ} \mathrm{S}$ until AABW reaches the equator (van Heuven et al., 2011). Due to dramatical change of properties after passing the equator, especially the sudden decrease of silicate, AABW is redefined as a new SWT, NEABW, in the north of equator. In the north of equator, water mass of NEABW origins from the newly defined SWT of NEWBW and as actually a continuation of AABW, becomes the dominate bottom water. Similar with AABW, NEABW also mainly mixed with lower NADW between equator and $40{ }^{\circ} \mathrm{N}$. In north of $40{ }^{\circ} \mathrm{N}, \mathrm{NEABW}$ spreads further north until $\sim 50^{\circ} \mathrm{N}$, where it meets lower NADW origins from ISOW (Garcia-Ibanez et al., 2015).

In the A16 section in Figure 11, AABW sinks to the bottom between $\sim 50-60{ }^{\circ} \mathrm{S}$ and spreads north to equator in the bottom layer below $4000 \mathrm{~m}\left(\sigma_{\theta}>27.88 \mathrm{~kg} / \mathrm{m}^{3}\right)$. After passing the ACC at $\sim 40{ }^{\circ} \mathrm{S}$, AABW meets upper NADW that is, in general, deflected upwards. During this process, part of AABW penetrate into the Deep and Overflow Layer $\left(\sigma_{\theta}\right.$ between 27.7 and $27.88 \mathrm{~kg} / \mathrm{m} 3$ ), so $\sim 20-50 \%$ of AABW can be seen in this layer in both the meridional (A16) and the zonal (A10) section. In the further north region, between $40^{\circ} \mathrm{S}$ and the equator, AABW contacts mainly with lower NADW instead of upper NADW. The fraction of AABW also increases with pressure. North of equator, NEABW is the only bottom water mass and distributes in the bottom in both sides of the MAR with the main core located below $\sim 4000 \mathrm{~m}$ with $\sigma_{\theta}>27.88 \mathrm{~kg} / \mathrm{m}^{3}$. Observations from the A16 and A05 sections show NEABW in contact with lower NADW from the above and the fraction of NEABW increases with depth.

\subsection{The Southern Water masses: WSBW, CDW, and AABW}

In this section the formation of AABW in the Weddell Sea Region is investigated and displayed, Figure 12. Similarly to the situation of NADW, AABW originates from two initial water masses, CDW and WSBW in the Antarctic region. An additional section, SR04 is analyzed to display the detail about formation of AABW. The SR04 section in the Weddell Sea region is formed by two parts representing the formation of $\mathrm{AABW}$ in both the meridional and zonal directions. 
Ocean Sci. Discuss., https://doi.org/10.5194/os-2018-140

Manuscript under review for journal Ocean Sci.

Discussion started: 17 January 2019

(c) Author(s) 2019. CC BY 4.0 License.

In the zonal section across the Weddell Sea, AABW can be seen as the product from two original water masses, CDW and WSBW. The core of CDW distributes in the upper 1000m and WSBW origins at the surface and subducts along the continental slope into the bottom below 4000m. This result is consistent with (van Heuven et al., 2011). Both original water masses meet each other at depth between $\sim 2000$ and $4000 \mathrm{~m}$, where AABW is formed with main core locates at $\sim 3000 \mathrm{~m}$.

The meridional section of SR04 cruise shows the northward outflow of AABW into the Atlantic Ocean. AABW is located between 2000 and $4000 \mathrm{~m}$, as a product from CDW and WSBW. After leaving Weddell Sea region, AABW is considered as an independent water mass from north of $60^{\circ} \mathrm{S}$ and spreads further northward as the only bottom water mass until the equator. In relative low latitude region (north of $60^{\circ} \mathrm{S}$ ), AAIW can also be found in shallow layer, since here is the boundary between formation area of AAIW and AABW.

\section{Conclusion and Discussion}

In this study, the distributions of water masses in Atlantic Ocean are investigated based on the GLODAPv2 dataset and the definition of water masses presented by (Liu and Tanhua, 2019). We have shown maps and sections of water mass distribution through the Atlantic Ocean basin. Water masses are mostly distributed within the density layer where they are formed, and mixing of water masses away from their formation areas are evident..

The central water masses, ENACW WNACW ESACW and WSACW, occupy the upper/central layer of the Atlantic Ocean by following the dividing line $\sigma_{\theta}<27 \mathrm{~kg} / \mathrm{m} 3$ and high salinity is also one significant property to identity them. Below the Upper layer, SAIW and MOW are the two main water masses in the intermediate layer in North Atlantic. SAIW comes from the northwest, sinks during the way to the southeast. In the eastern part, MOW overflows from the Mediterranean Sea, across the Strait of Gibraltar and spreads to the north and west. The most significant property of MOW is high salinity at around $1000 \mathrm{~m}$ depth. In the South Atlantic, AAIW is the dominate water mass in intermediate layer. After the formation in the shallow layer, AAIW sinks into intermediate depth (around 1000m) and spreads to the north until $\sim 40{ }^{\circ} \mathrm{N}$ and this water mass can easily be found with low salinity.

NADW is the main water mass in the Deep and Overflow Layer. In order to show more clearly the distribution of water masses in this layer, more detail are investigated to display upper and lower NADW, as well as their origin, LSW, ISOW and DSOW, separately.

For the bottom waters, AABW and NEABW, have similar properties, especially high silicate content, since NEABW, traced back to the source, is a branch from AABW after passing the equator. After spanning most Atlantic there is a sharp reduction of silicate concentration, the new defined SWT, NEABW becomes the dominate water mass in the bottom. 
Ocean Sci. Discuss., https://doi.org/10.5194/os-2018-140

Manuscript under review for journal Ocean Sci.

Discussion started: 17 January 2019

(c) Author(s) 2019. CC BY 4.0 License.

\section{Acknowledgements}

This work is based on the comprehensive and detailed data from GLODAP data set throughout the past few decades and we would like to thank the efforts from all the scientists and crews on cruises and the working groups of GLODAP for their contributions and selfless sharing. In particular, we are grateful to the theoretical and technical support from J. Karstensen and M. Tomczak for the OMP analysis. Thanks to the China Scholarship Council (CSC) for providing funding support to Mian Liu's PhD study in GEOMAR Helmholtz Centre for Ocean Research Kiel.

\section{References}

Alvarez, M., Brea, S., Mercier, H., Alvarez-Salgado, X.A.: Mineralization of biogenic materials in the water masses of the South Atlantic Ocean. I: Assessment and results of an optimum multiparameter analysis. Prog Oceanogr 123, 1-23, 2014.

Broecker, W.S.: No a Conservative Water-Mass Tracer. Earth Planet Sc Lett 23, 100-107, 1974.

Carracedo, L., Pardo, P.C., Flecha, S., Pérez, F.F.: On the Mediterranean Water Composition. Journal of Physical Oceanography 46, 1339-1358, 2016.

Clarke, R.A., Gascard, J.-C.: The Formation of Labrador Sea Water. Part I: Large-Scale Processes. Journal of Physical Oceanography 13, 1764-1778, 1983.

Clarke, R.A., Swift, J.H., Reid, J.L., Koltermann, K.P.: The formation of Greenland Sea Deep Water: double diffusion or deep convection? Deep Sea Research Part A. Oceanographic Research Papers 37, 1385-1424, 1990.

Deruijter, W.: Asymptotic Analysis of the Agulhas and Brazil Current Systems. Journal of Physical Oceanography 12, 361373, 1982.

Elliot, M., Labeyrie, L., Duplessy, J.C.: Changes in North Atlantic deep-water formation associated with the DansgaardOeschger temperature oscillations (60-10 ka). Quaternary Science Reviews 21, 1153-1165, 2002.

Emery, W.J., Meincke, J.: Global Water Masses - Summary and Review. Oceanologica Acta 9, 383-391, 1986.

Fyfe, J.C., Saenko, O.A., Zickfeld, K., Eby, M., Weaver, A.J.: The role of poleward-intensifying winds on Southern Ocean warming. Journal of Climate 20, 5391-5400, 2007.

Garcia-Ibanez, M.I., Pardo, P.C., Carracedo, L.I., Mercier, H., Lherminier, P., Rios, A.F., Perez, F.F.: Structure, transports and transformations of the water masses in the Atlantic Subpolar Gyre. Prog Oceanogr 135, 18-36, 2015.

Hinrichsen, H.H., Tomczak, M.: Optimum multiparameter analysis of the water mass structure in the western North Atlantic Ocean. Journal of Geophysical Research: Oceans 98, 10155-10169, 1993.

Ishii, M., Suzuki, T., Key, R.: Pacific Ocean Interior Carbon Data Synthesis, PACIFICA, in Progress. PICES Press 19, 20, 2011.

Karstensen, J., Stramma, L., Visbeck, M.: Oxygen minimum zones in the eastern tropical Atlantic and Pacific oceans. Prog Oceanogr 77, 331-350, 2008. 
Ocean Sci. Discuss., https://doi.org/10.5194/os-2018-140

Manuscript under review for journal Ocean Sci.

Discussion started: 17 January 2019

(c) Author(s) 2019. CC BY 4.0 License.

Karstensen, J., Tomczak, M.: Ventilation processes and water mass ages in the thermocline of the southeast Indian Ocean. Geophysical Research Letters 24, 2777-2780, 1997.

Karstensen, J., Tomczak, M.: Age determination of mixed water masses using CFC and oxygen data. Journal of Geophysical Research: Oceans 103, 18599-18609, 1998a.

Karstensen, J., Tomczak, M.: Age determination of mixed water masses using CFC and oxygen data. J Geophys Res-Oceans 103, 18599-18609, 1998b.

Key, R.M., Kozyr, A., Sabine, C.L., Lee, K., Wanninkhof, R., Bullister, J.L., Feely, R.A., Millero, F.J., Mordy, C., Peng, T.H.: A global ocean carbon climatology: Results from Global Data Analysis Project (GLODAP). Global biogeochemical cycles 18, 2004.

Key, R.M., Tanhua, T., Olsen, A., Hoppema, M., Jutterström, S., Schirnick, C., van Heuven, S., Kozyr, A., Lin, X., Velo, A., Wallace, D.W.R., Mintrop, L.: The CARINA data synthesis project: introduction and overview. Earth Syst. Sci. Data 2, 105$121,2010$.

Kieke, D., Rhein, M., Stramma, L., Smethie, W.M., Bullister, J.L., LeBel, D.A.: Changes in the pool of Labrador Sea Water in the subpolar North Atlantic. Geophysical Research Letters 34, 2007.

Kieke, D., Rhein, M., Stramma, L., Smethie, W.M., LeBel, D.A., Zenk, W.: Changes in the CFC inventories and formation rates of Upper Labrador Sea Water, 1997-2001. Journal of Physical Oceanography 36, 64-86, 2006.

Kirchner, K., Rhein, M., Huttl-Kabus, S., Boning, C.W.: On the spreading of South Atlantic Water into the Northern Hemisphere. J Geophys Res-Oceans 114, 2009.

Kissel, C., Laj, C., Lehman, B., Labyrie, L., Bout-Roumazeilles, V.: Changes in the strength of the Iceland-Scotland Overflow Water in the last 200,000 years: Evidence from magnetic anisotropy analysis of core SU90-33. Earth Planet Sc Lett 152, 25-36, 1997.

Klein, B., Hogg, N.: On the variability of 18 Degree Water formation as observed from moored instruments at 55 degrees W. Deep-Sea Research Part I-Oceanographic Research Papers 43, 1777-\&,1996.

Klein, B., Tomczak, M.: Identification of diapycnal mixing through optimum multiparameter analysis: 2. Evidence for unidirectional diapycnal mixing in the front between North and South Atlantic Central Water. Journal of Geophysical Research: Oceans 99, 25275-25280, 1994.

Kuhlbrodt, T., Griesel, A., Montoya, M., Levermann, A., Hofmann, M., Rahmstorf, S.: On the driving processes of the Atlantic meridional overturning circulation. Reviews of Geophysics 45, 2007.

Lacan, F., Jeandel, C.: Neodymium isotopic composition and rare earth element concentrations in the deep and intermediate Nordic Seas: Constraints on the Iceland Scotland Overflow Water signature. Geochemistry Geophysics Geosystems 5, 2004.

Lauvset, S.K., Key, R.M., Olsen, A., van Heuven, S., Velo, A., Lin, X., Schirnick, C., Kozyr, A., Tanhua, T., Hoppema, M., Jutterström, S., Steinfeldt, R., Jeansson, E., Ishii, M., Perez, F.F., Suzuki, T., Watelet, S.: A new global interior ocean mapped climatology: the $1^{\circ} \times 1^{\circ}$ GLODAP version 2. Earth Syst. Sci. Data 8, 325-340, 2016.

Lazier, J.R.N., Wright, D.G.: Annual Velocity Variations in the Labrador Current. Journal of Physical Oceanography 23, 659-678, 1993. 
Ocean Sci. Discuss., https://doi.org/10.5194/os-2018-140

Manuscript under review for journal Ocean Sci.

Discussion started: 17 January 2019

(c) Author(s) 2019. CC BY 4.0 License.

Lozier, M.S.: Overturning in the North Atlantic. Ann Rev Mar Sci 4, 291-315, 2012.

Lutjeharms, J.R., van Ballegooyen, R.C.: Anomalous upstream retroflection in the agulhas current. Science 240, 1770, 1988.

Mackas, D.L., Denman, K.L., Bennett, A.F.: Least squares multiple tracer analysis of water mass composition. Journal of Geophysical Research: Oceans 92, 2907-2918, 1987.

McCartney, M.S.: The subtropical recirculation of Mode Waters. J Mar Res 40, 427-464, 1982.

McCartney, M.S., Talley, L.D.: The subpolar mode water of the North Atlantic Ocean. Journal of Physical Oceanography $12,1169-1188,1982$.

Peterson, R.G., Stramma, L.: Upper-Level Circulation in the South-Atlantic Ocean. Prog Oceanogr 26, 1-73, 1991.

Pickart, R.S., Spall, M.A., Lazier, J.R.N.: Mid-depth ventilation in the western boundary current system of the sub-polar gyre. Deep-Sea Research Part I-Oceanographic Research Papers 44, 1025-+,1997.

Poole, R., Tomczak, M.: Optimum multiparameter analysis of the water mass structure in the Atlantic Ocean thermocline. Deep-Sea Research Part I-Oceanographic Research Papers 46, 1895-1921, 1999.

Price, J.F., Baringer, M.O., Lueck, R.G., Johnson, G.C., Ambar, I., Parrilla, G., Cantos, A., Kennelly, M.A., Sanford, T.B.: Mediterranean outflow mixing and dynamics. Science 259, 1277-1282, 1993.

Read, J.: CONVEX-91: water masses and circulation of the Northeast Atlantic subpolar gyre. Prog Oceanogr 48, 461-510, 2000 .

Rhein, M., Kieke, D., Huttl-Kabus, S., Roessler, A., Mertens, C., Meissner, R., Klein, B., Boning, C.W., Yashayaev, I.: Deep water formation, the subpolar gyre, and the meridional overturning circulation in the subpolar North Atlantic. Deep-Sea Research Part Ii-Topical Studies in Oceanography 58, 1819-1832, 2011.

Rudels, B., Fahrbach, E., Meincke, J., Budéus, G., Eriksson, P.: The East Greenland Current and its contribution to the Denmark Strait overflow. ICES Journal of Marine Science 59, 1133-1154, 2002.

Smethie Jr, W.M.: Tracing the thermohaline circulation in the western North Atlantic using chlorofluorocarbons. Prog Oceanogr 31, 51-99, 1993.

Smethie, W.M., Fine, R.A.: Rates of North Atlantic Deep Water formation calculated from chlorofluorocarbon inventories. Deep-Sea Research Part I-Oceanographic Research Papers 48, 189-215, 2001.

Smith, E.H., Soule, F.M., Mosby, O.: The Marion and General Greene Expeditions to Davis Strait and Labrador Sea, Under Direction of the United States Coast Guard: 1928-1931-1933-1934-1935: Scientific Results, Part 2: Physical Oceanography. US Government Printing Office, 1937.

Stramma, L., England, M.H.: On the water masses and mean circulation of the South Atlantic Ocean. J Geophys Res-Oceans 104, 20863-20883, 1999.

Sverdrup: The Oceans: Their Physics, Chemistry and General Biology, 1942.

Swift, J.H.: The Circulation of the Denmark Strait and Iceland Scotland Overflow Waters in the North-Atlantic. Deep-Sea Research Part a-Oceanographic Research Papers 31, 1339-1355, 1984. 
Ocean Sci. Discuss., https://doi.org/10.5194/os-2018-140

Manuscript under review for journal Ocean Sci.

Discussion started: 17 January 2019

(c) Author(s) 2019. CC BY 4.0 License.

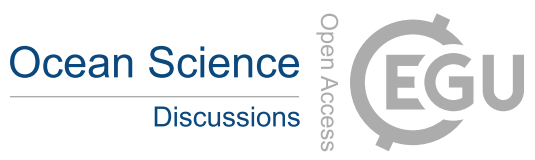

(c) (i)

525 Swift, S.M.: Activity patterns of pipistrelle bats (Pipistrellus pipistrellus) in north- east Scotland. Journal of Zoology 190, $526 \quad 285-295,1980$.

527 Talley, L.: Antarctic intermediate water in the South Atlantic, The South Atlantic. Springer, pp. 219-238, 1996.

528 Talley, L., Raymer, M.: Eighteen degree water variability. J. Mar. Res 40, 757-775, 1982.

529 Talley, L.D., Mccartney, M.S.: Distribution and Circulation of Labrador Sea-Water. Journal of Physical Oceanography 12, $530 \quad 1189-1205,1982$.

531 Tanhua, T., Olsson, K.A., Jeansson, E.: Formation of Denmark Strait overflow water and its hydro-chemical composition. 532 Journal of Marine Systems 57, 264-288, 2005.

533 Tomczak, M.: A multi-parameter extension of temperature/salinity diagram techniques for the analysis of non-isopycnal 534 mixing. Prog Oceanogr 10, 147-171, 1981.

535 Tomczak, M., Large, D.G.: Optimum multiparameter analysis of mixing in the thermocline of the eastern Indian Ocean. 536 Journal of Geophysical Research: Oceans 94, 16141-16149, 1989.

537 van Heuven, S.M.A.C., Hoppema, M., Huhn, O., Slagter, H.A., de Baar, H.J.W.: Direct observation of increasing CO2 in the 538 Weddell Gyre along the Prime Meridian during 1973-2008. Deep Sea Research Part II: Topical Studies in Oceanography 58, 539 2613-2635, 2011.

540 Weiss, R.F., Ostlund, H.G., Craig, H.: Geochemical Studies of the Weddell Sea. Deep-Sea Research Part a-Oceanographic 541 Research Papers 26, 1093-1120, 1979.

542 Wüst, G., Defant, A.: Atlas zur Schichtung und Zirkulation des Atlantischen Ozeans: Schnitte und Karten von Temperatur, 543 Salzgehalt und Dichte. W. de Gruyter, 1936. 
Ocean Sci. Discuss., https://doi.org/10.5194/os-2018-140

Manuscript under review for journal Ocean Sci.

Discussion started: 17 January 2019

(C) Author(s) 2019. CC BY 4.0 License.

\section{(c) (1)}
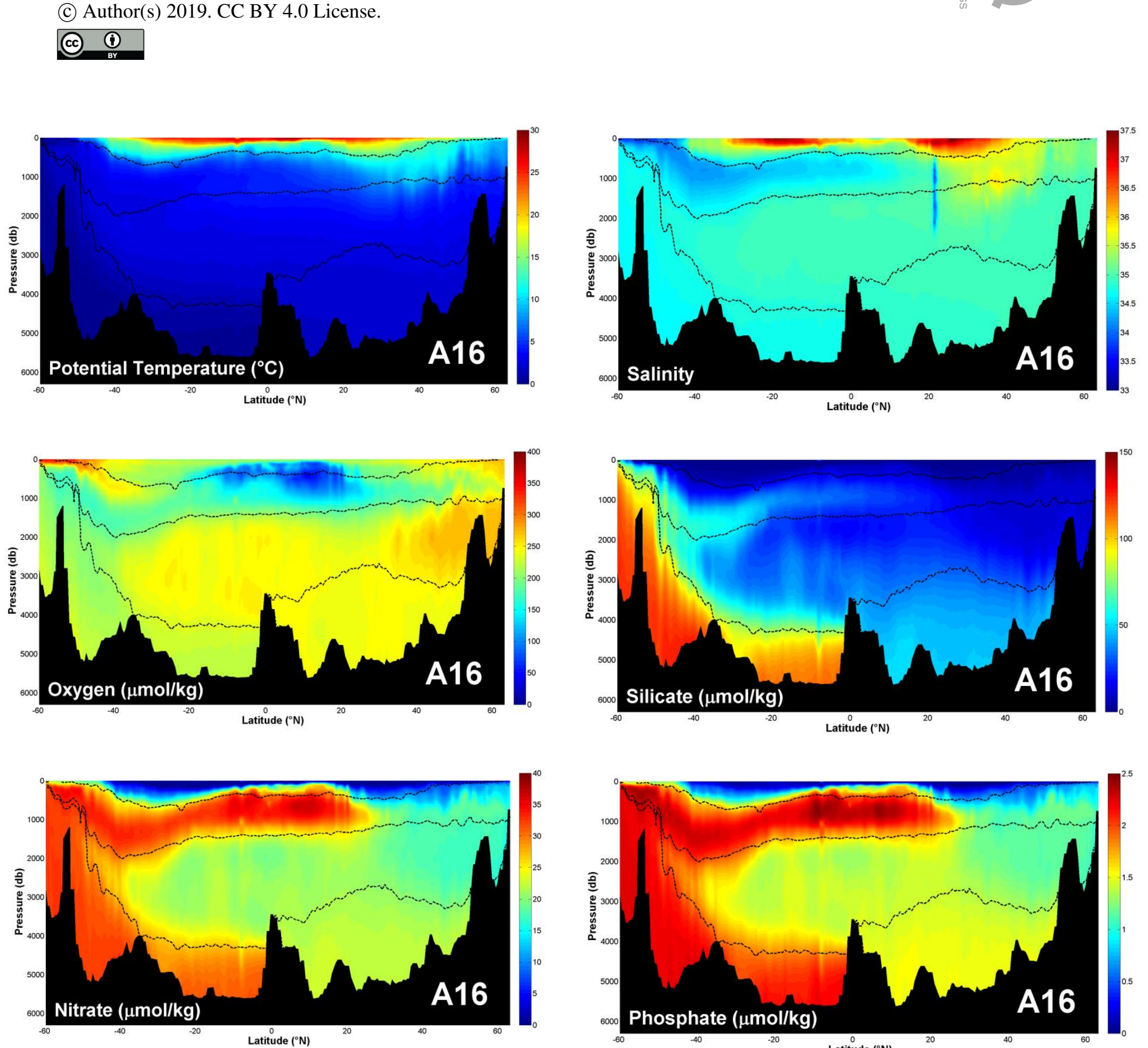

Ocean Science

Discussions

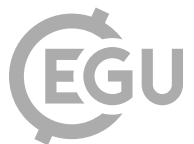


Ocean Sci. Discuss., https://doi.org/10.5194/os-2018-140

Manuscript under review for journal Ocean Sci.

Discussion started: 17 January 2019

(c) Author(s) 2019. CC BY 4.0 License.

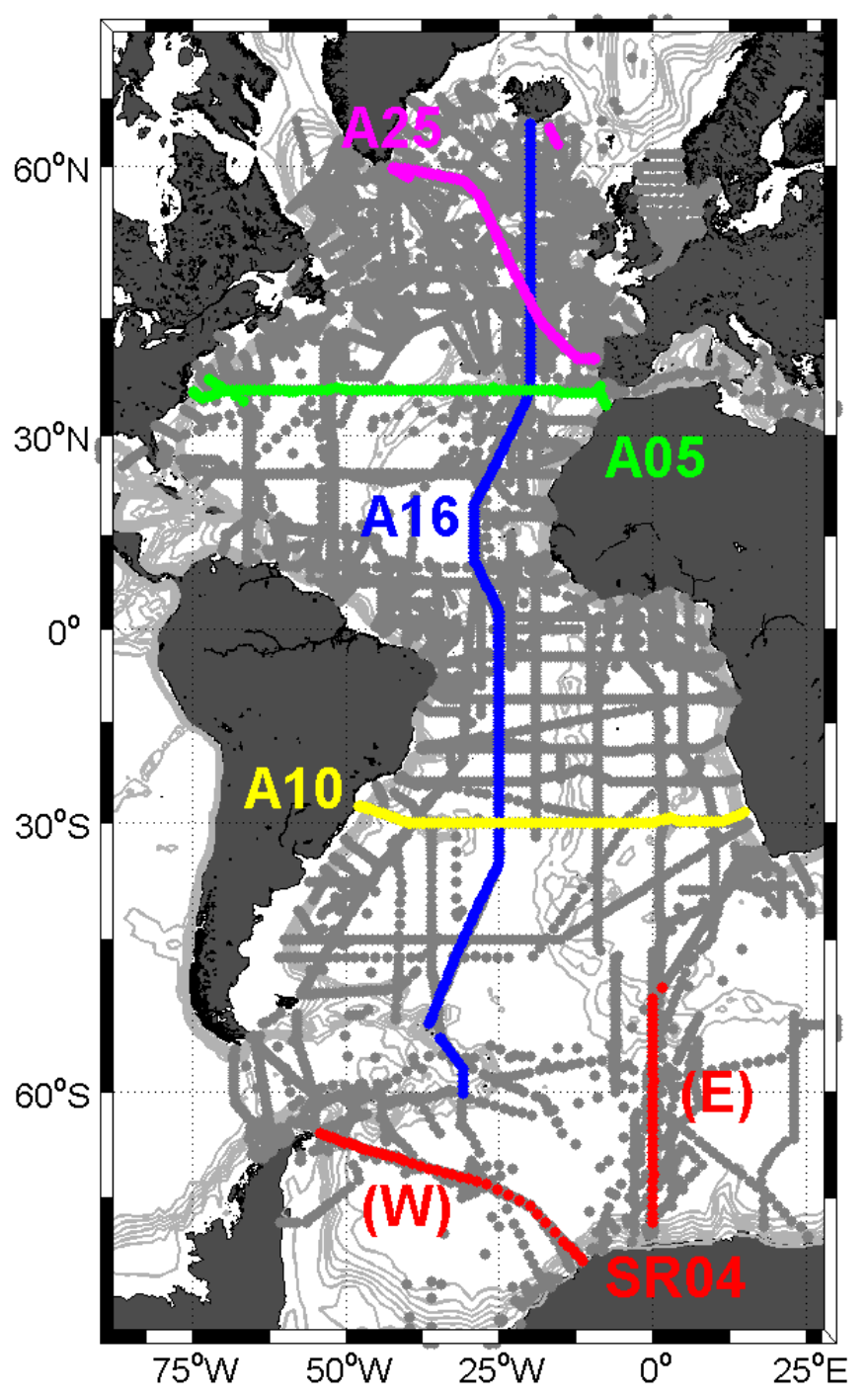

Fig 2 Maps of Cruises

Color lines show representative cruises analyzed in this paper while gray dots show all the GLODAPv2 stations 
Ocean Sci. Discuss., https://doi.org/10.5194/os-2018-140

Manuscript under review for journal Ocean Sci.

Discussion started: 17 January 2019

(c) Author(s) 2019. CC BY 4.0 License.

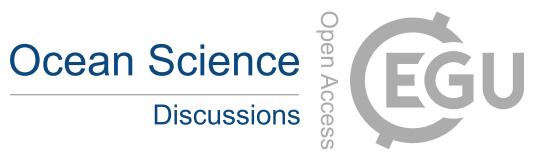

\section{(c) (1)}
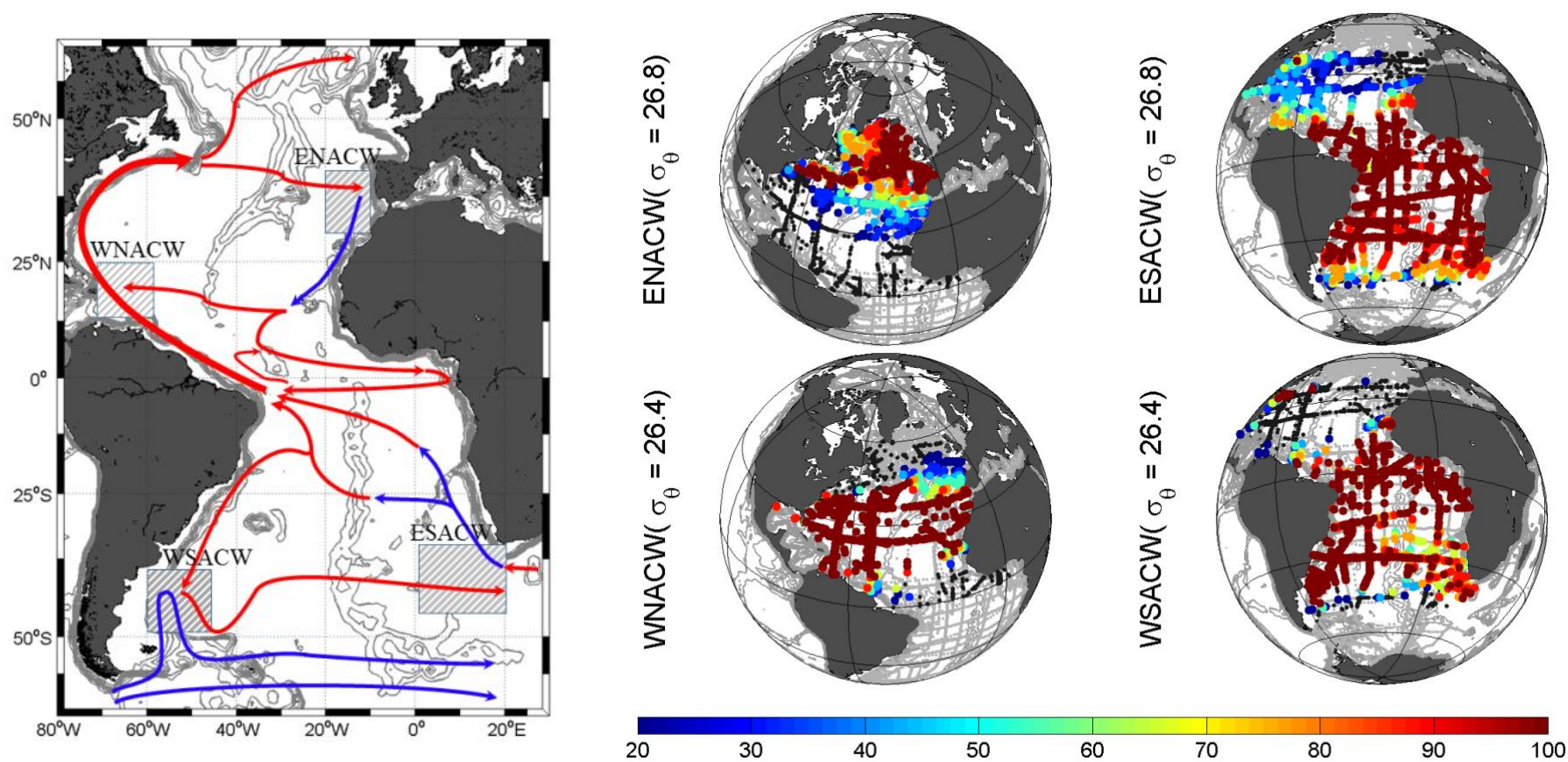

Fig. 3 Currents (left) and Water Masses (right) in the Upper Layer

Left: The arrows show the warm (red) and cold (blue) currents and rectangular shadow areas show the formation areas of water masses in the Upper Layer.

Right: Color dots show fractions (from $20 \%$ to $100 \%$ ) of water masses in each station around core potential density $\left(\mathrm{kg} / \mathrm{m}^{3}\right) . \mathrm{Stations}$ with fractions less than $20 \%$ are marked by black dots while gray dots show the GLODAPv2 stations without specified water mass. 

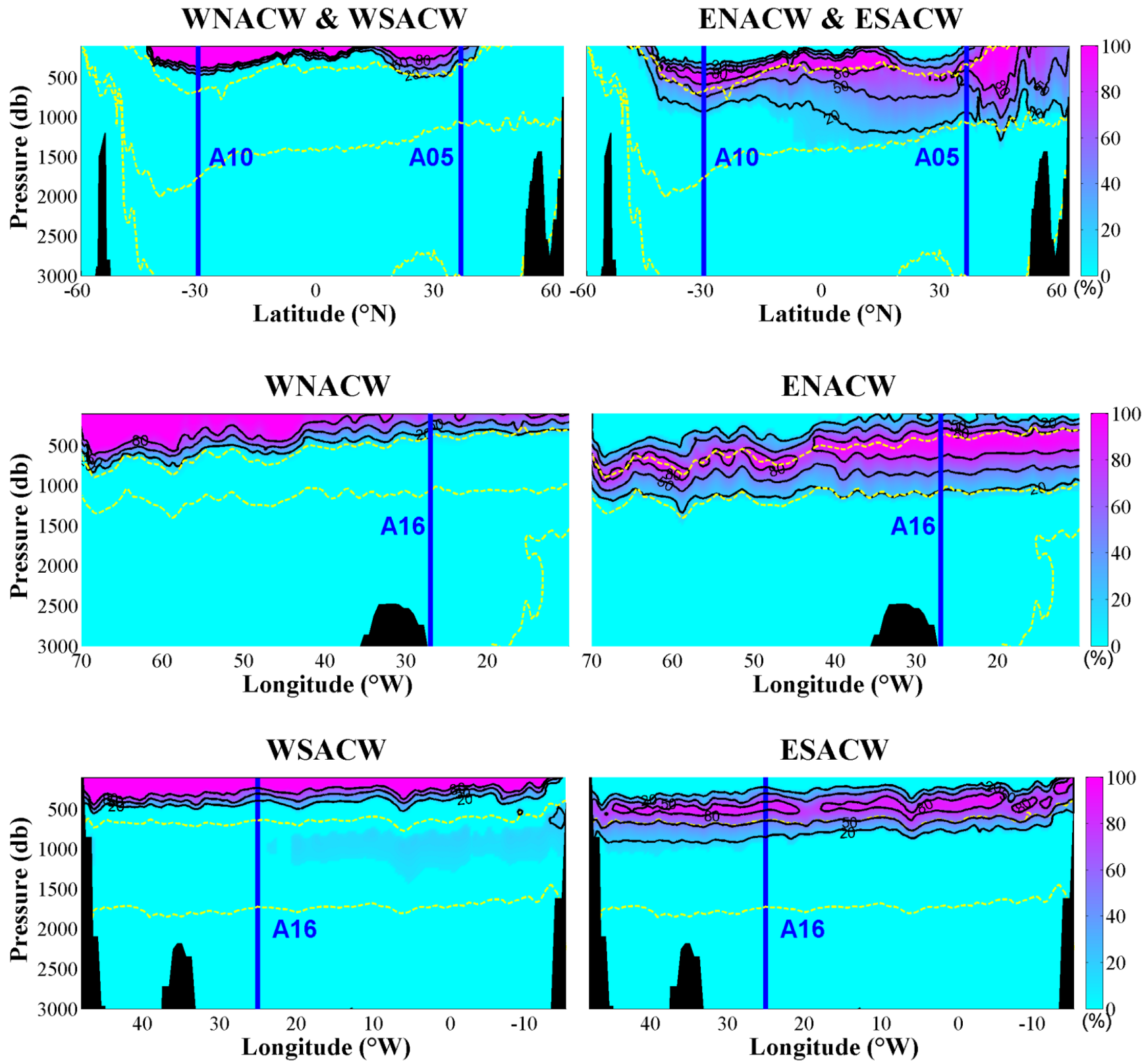

Fig. 4 Distribution of Central Water Masses based on A16 (upper), A05 (middle), A10 (lower) cruises within 3000m

Contour lines show fractions of $20 \% \mathbf{5 0 \%}$ and $\mathbf{8 0} \%$, blue lines show cross section of other cruises, yellow dashed lines show the boundaries of vertical water columns layers (potential density at $27,27.7$ and $27.88 \mathrm{~kg} / \mathrm{m}^{3}$ ) 
Ocean Sci. Discuss., https://doi.org/10.5194/os-2018-140

Manuscript under review for journal Ocean Sci.

Discussion started: 17 January 2019

(c) Author(s) 2019. CC BY 4.0 License.

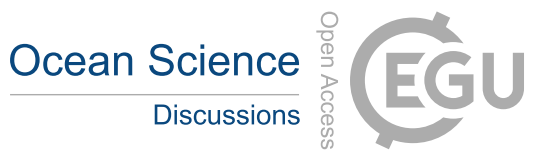

(c) (i)
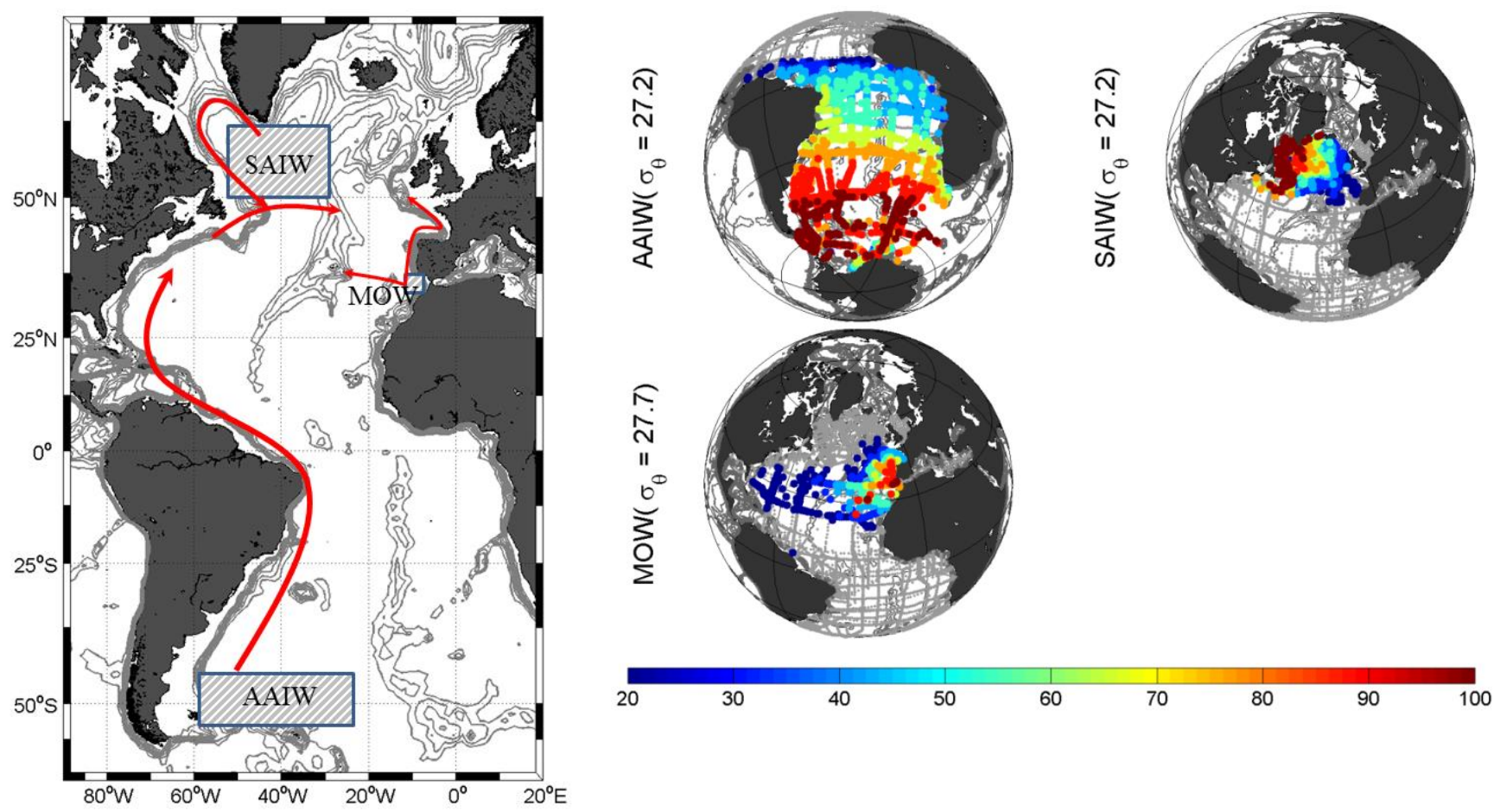

Fig.5 Currents (left) and Water Masses (right) in the Intermediate Layer

Left: The arrows show the currents and rectangular shadow areas show the formation areas of water masses in the Intermediate Layer.

Right: Color dots show fractions (from $20 \%$ to $100 \%)$ of water masses in each station around core potential density $\left(\mathrm{kg} / \mathrm{m}^{3}\right)$. Stations with fractions less than $20 \%$ are marked by black dots while gray dots show the GLODAPv2 stations without specified water mass. 

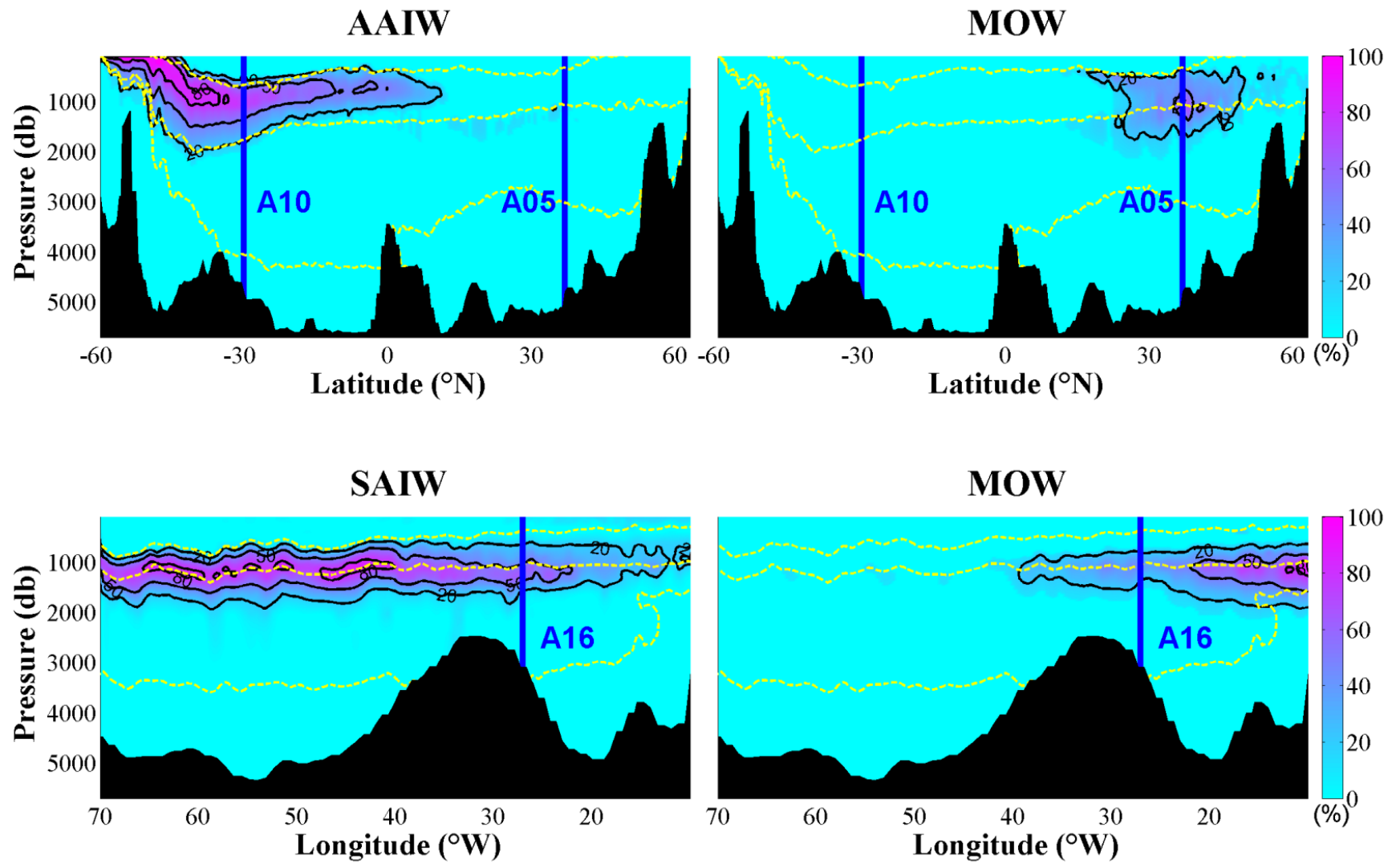

Fig. 6 Distribution of Water Masses in the Intermediate Layer based on A16 (upper) and A05 (lower) cruises

Contour lines show fractions of $20 \% \mathbf{5 0 \%}$ and $80 \%$, blue lines show cross section of other cruises, yellow dashed lines show the boundaries of vertical water columns layers (potential density at $27,27.7$ and $27.88 \mathrm{~kg} / \mathrm{m}^{3}$ ) 
Ocean Sci. Discuss., https://doi.org/10.5194/os-2018-140

Manuscript under review for journal Ocean Sci.

Discussion started: 17 January 2019

(c) Author(s) 2019. CC BY 4.0 License.
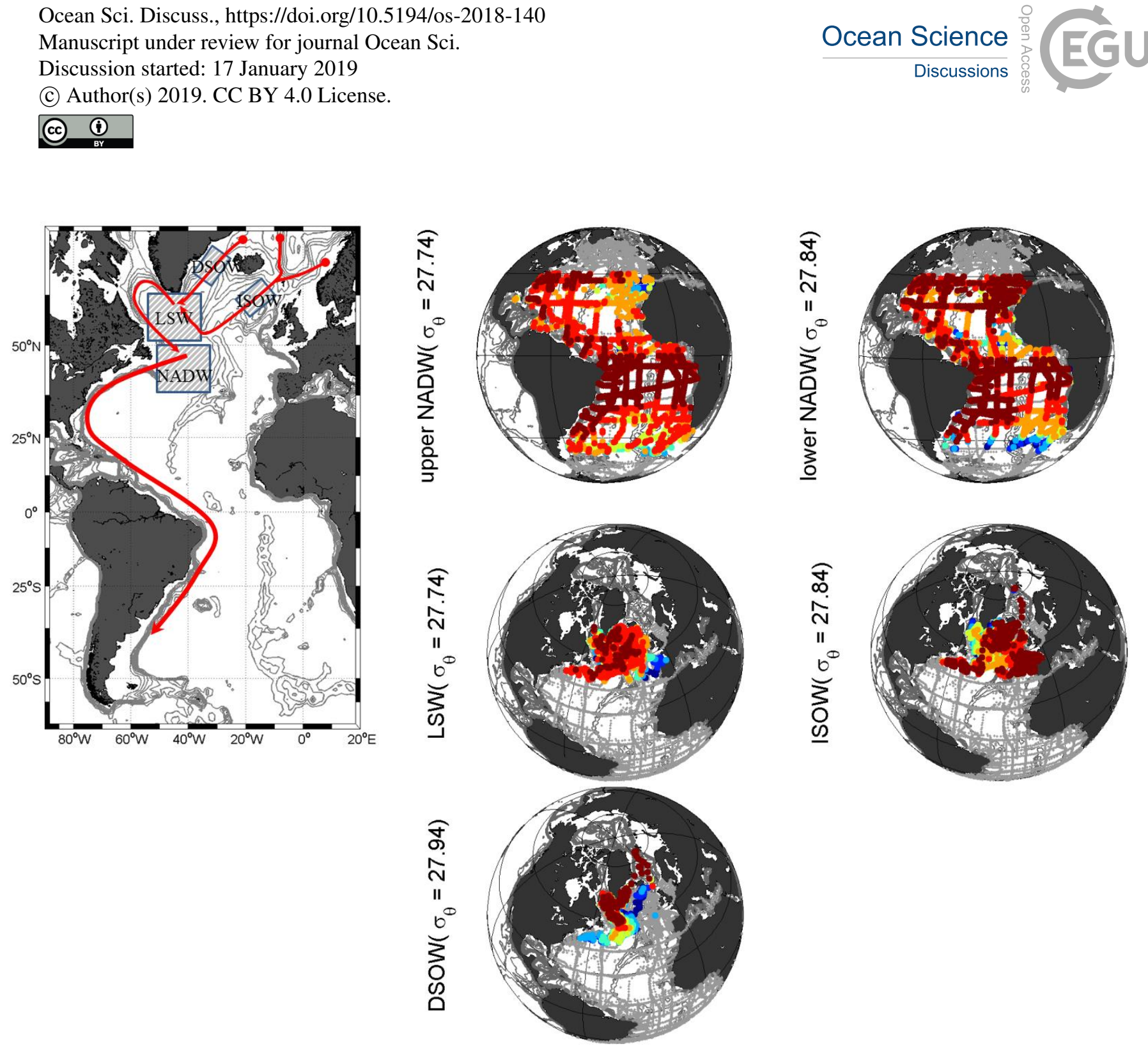

(c) (7)
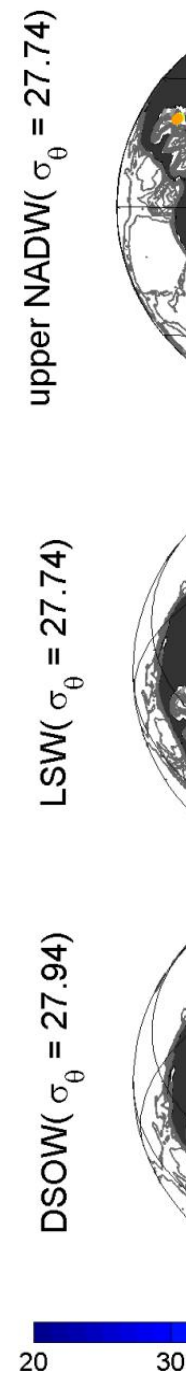

40

50

60

70

80

90 100

Fig.7 Currents (left) and Water Masses (right) in the Deep and Overflow Layer

Left: The arrows show the currents and rectangular shadow areas show the formation areas of water masses in the Deep and Overflow Layer.

Right: Color dots show fractions (from $20 \%$ to $100 \%)$ of water masses in each station around core potential density $\left(\mathrm{kg} / \mathrm{m}^{3}\right) . \mathrm{Stations}$ with fractions less than $20 \%$ are marked by black dots while gray dots show the GLODAPv2 stations without specified water mass. 


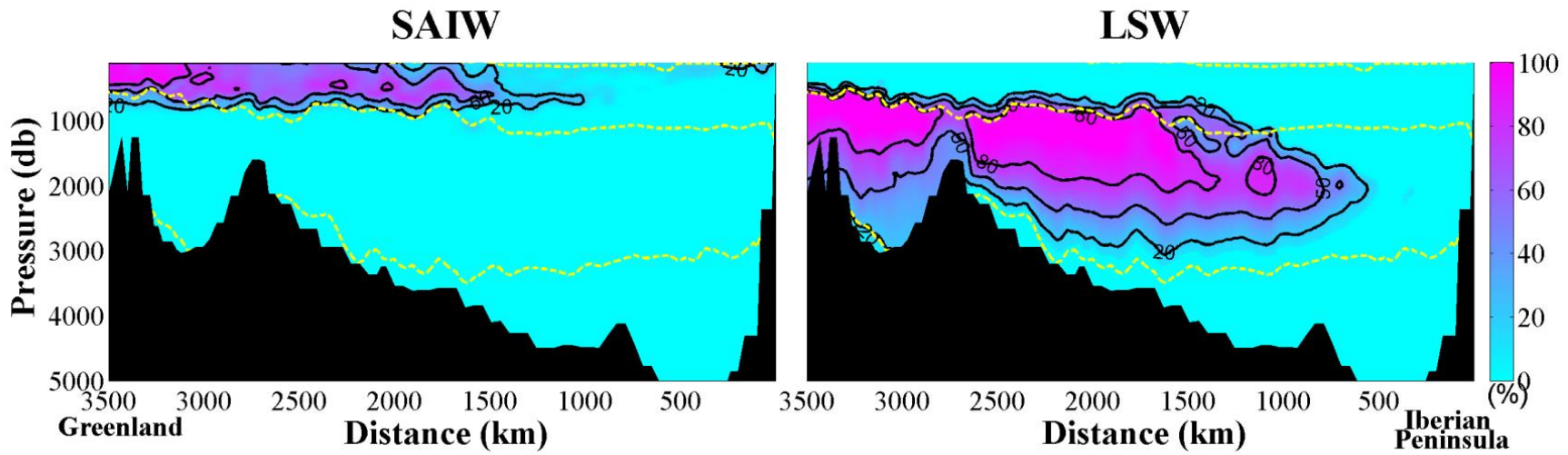

ISOW

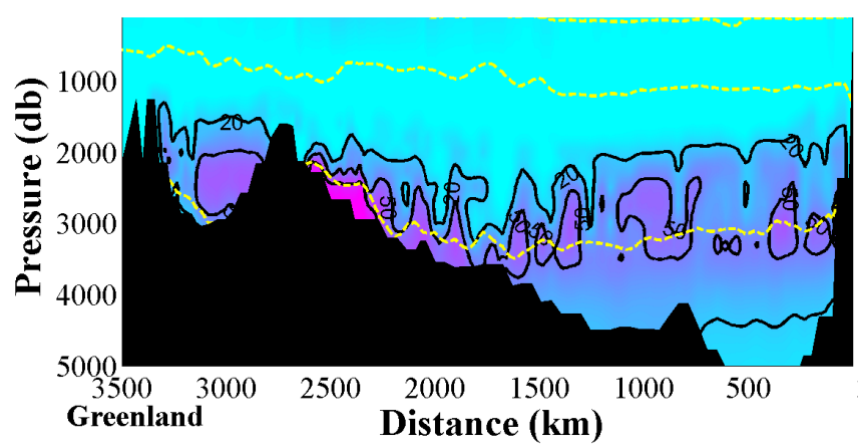

DSOW

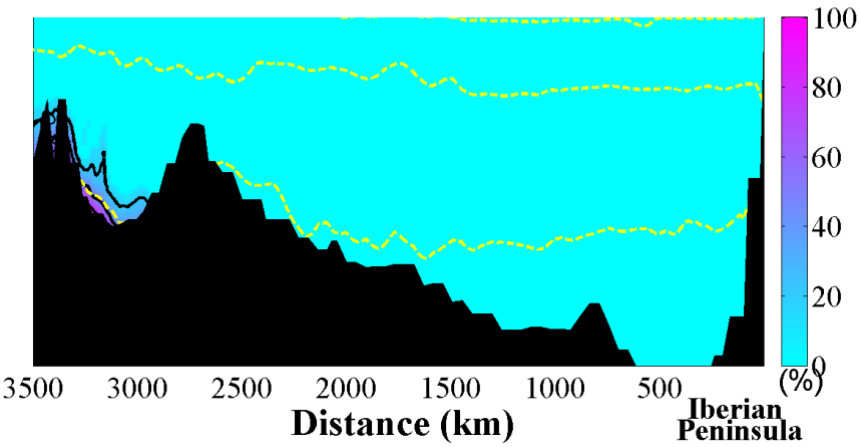

Fig. 8 Distribution of SAIW (upper left), LSW (upper right), ISOW (lower left) and DSOW (lower right) based on A25 cruise

Contour lines show fractions of $20 \% \mathbf{5 0 \%}$ and $\mathbf{8 0} \%$, blue lines show cross section of other cruises, yellow dashed lines show the boundaries of vertical water columns layers (potential density at $27,27.7$ and $27.88 \mathrm{~kg} / \mathrm{m}^{3}$ ) 

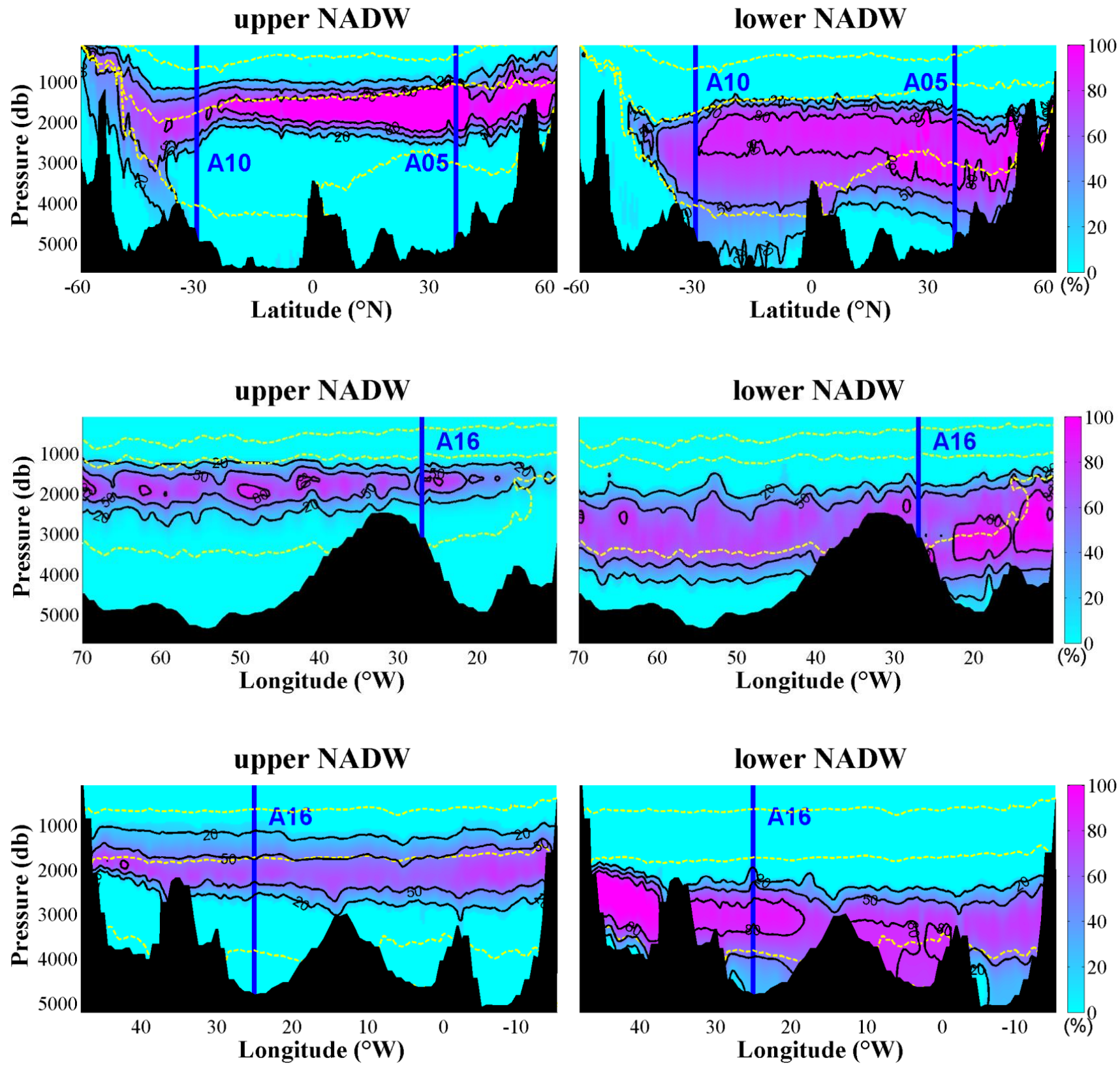

Fig. 9 Distribution of upper and lower NADW based on A16 (upper), A05 (middle) and A10 (lower) cruises

Contour lines show fractions of $20 \% \mathbf{5 0 \%}$ and $\mathbf{8 0} \%$, blue lines show cross section of other cruises, yellow dashed lines show the boundaries of vertical water columns layers (potential density at $27,27.7$ and $27.88 \mathrm{~kg} / \mathrm{m}^{3}$ ) 
Ocean Sci. Discuss., https://doi.org/10.5194/os-2018-140

Manuscript under review for journal Ocean Sci.

Discussion started: 17 January 2019

(c) Author(s) 2019. CC BY 4.0 License.

(c) (i)
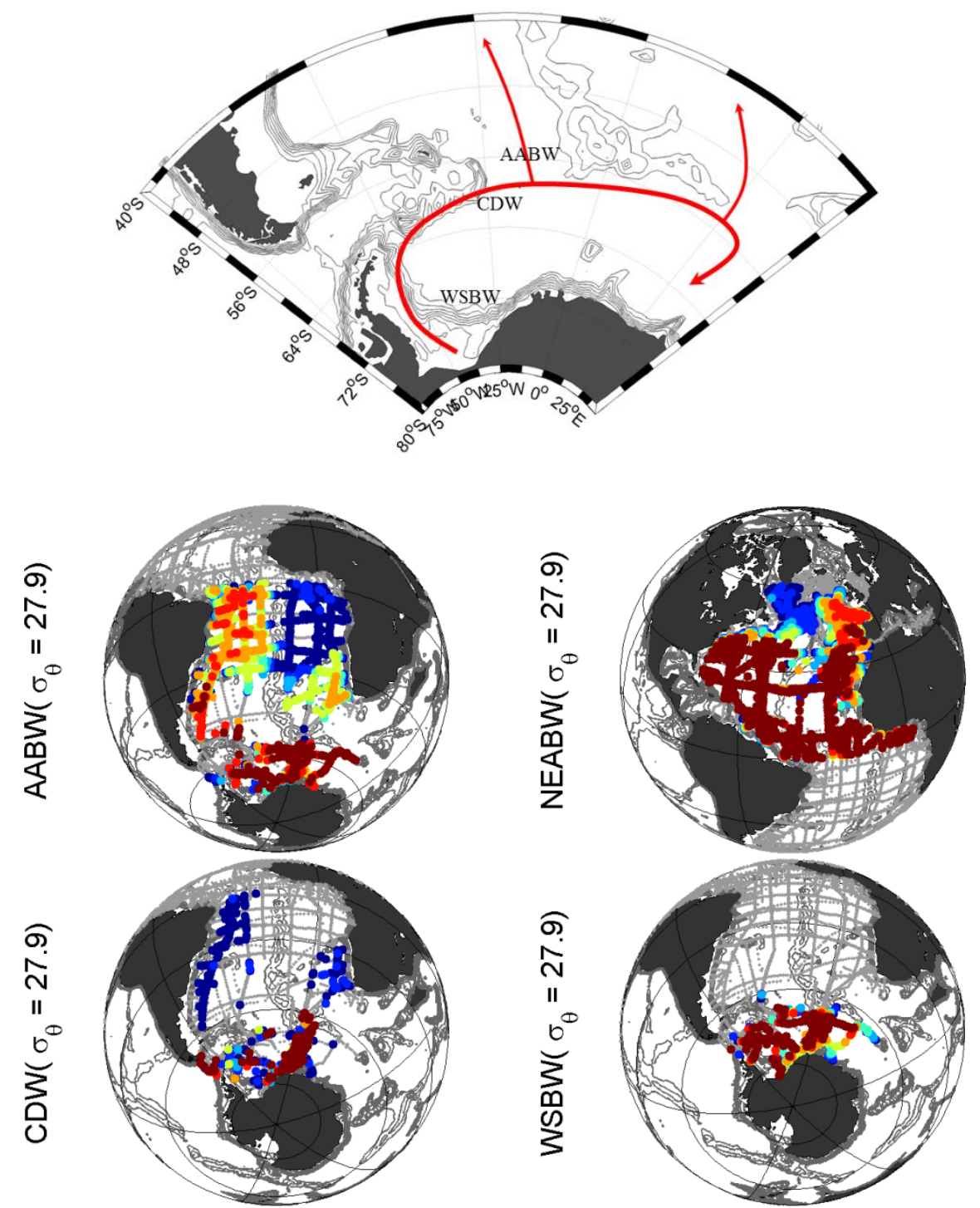

20

30

40

50

60

70

80

90

100

Fig.10 Currents (upper) and Water Masses (lower) in the Bottom Layer (AABW and NEABW) and the Southern Area (CDW and WSBW)

Upper: The arrows show the currents in the Southern Area.

Lower: Color dots show fractions (from $20 \%$ to 100\%) of water masses in each station around core potential density (kg/m3). Stations with fractions less than $20 \%$ are marked by black dots while gray dots show the GLODAPv2 stations without specified water mass. 
AABW

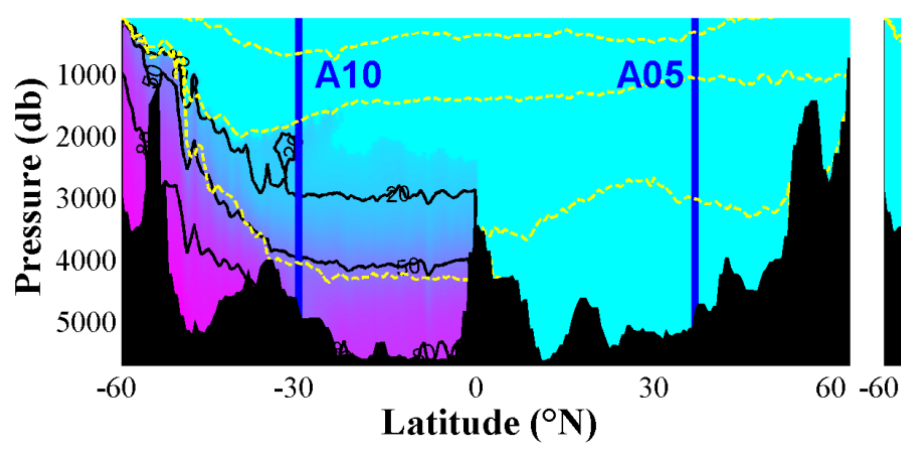

AABW

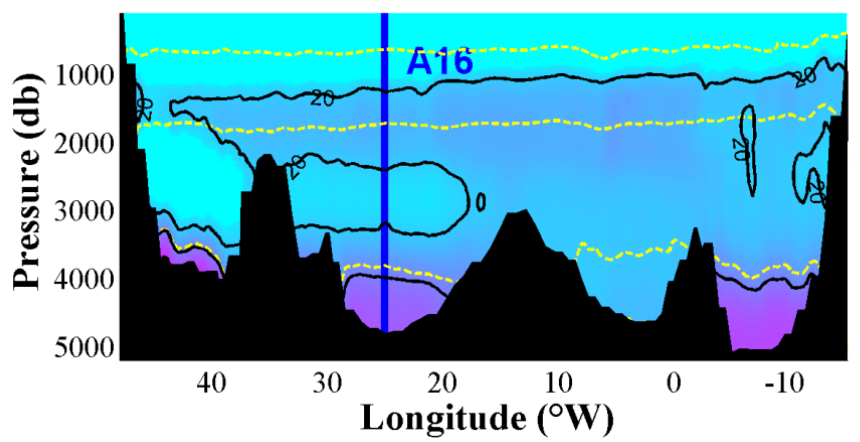

NEABW

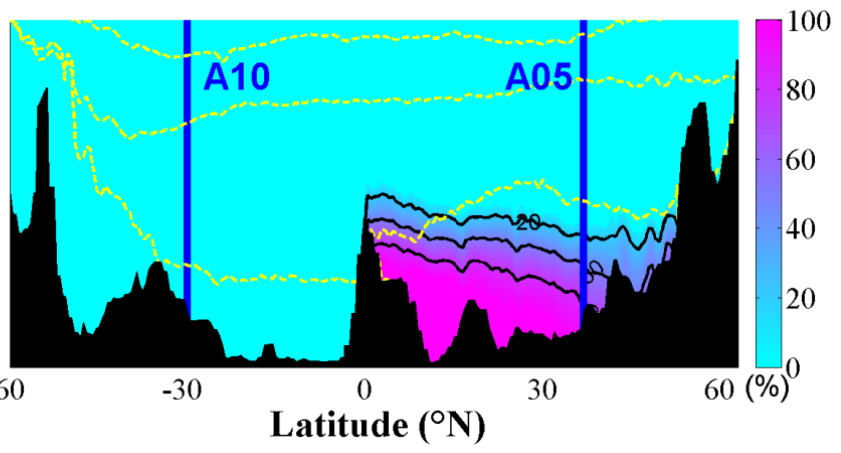

NEABW

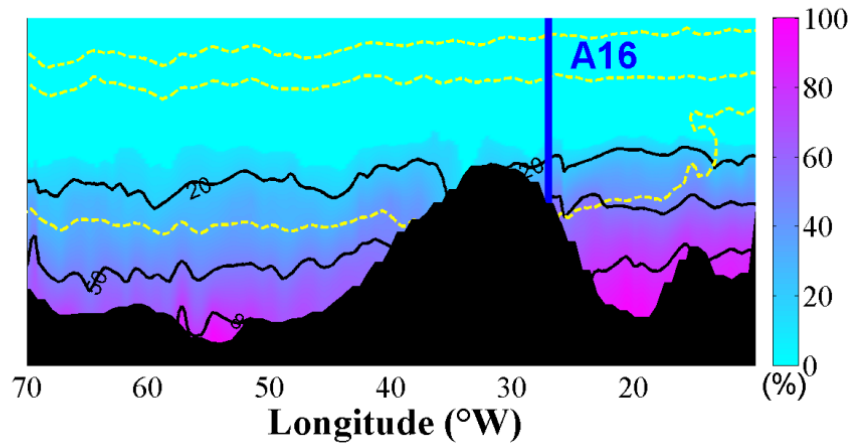

Fig. 11 Distribution of AABW and NEABW based on A16 (upper), A10 (lower left) and A05 (lower right) cruises

Contour lines show fractions of $20 \% \mathbf{5 0 \%}$ and $\mathbf{8 0 \%}$, blue lines show cross section of other cruises, yellow dashed lines show the boundaries of vertical water columns layers (potential density at $27,27.7$ and $27.88 \mathrm{~kg} / \mathrm{m}^{3}$ ) 

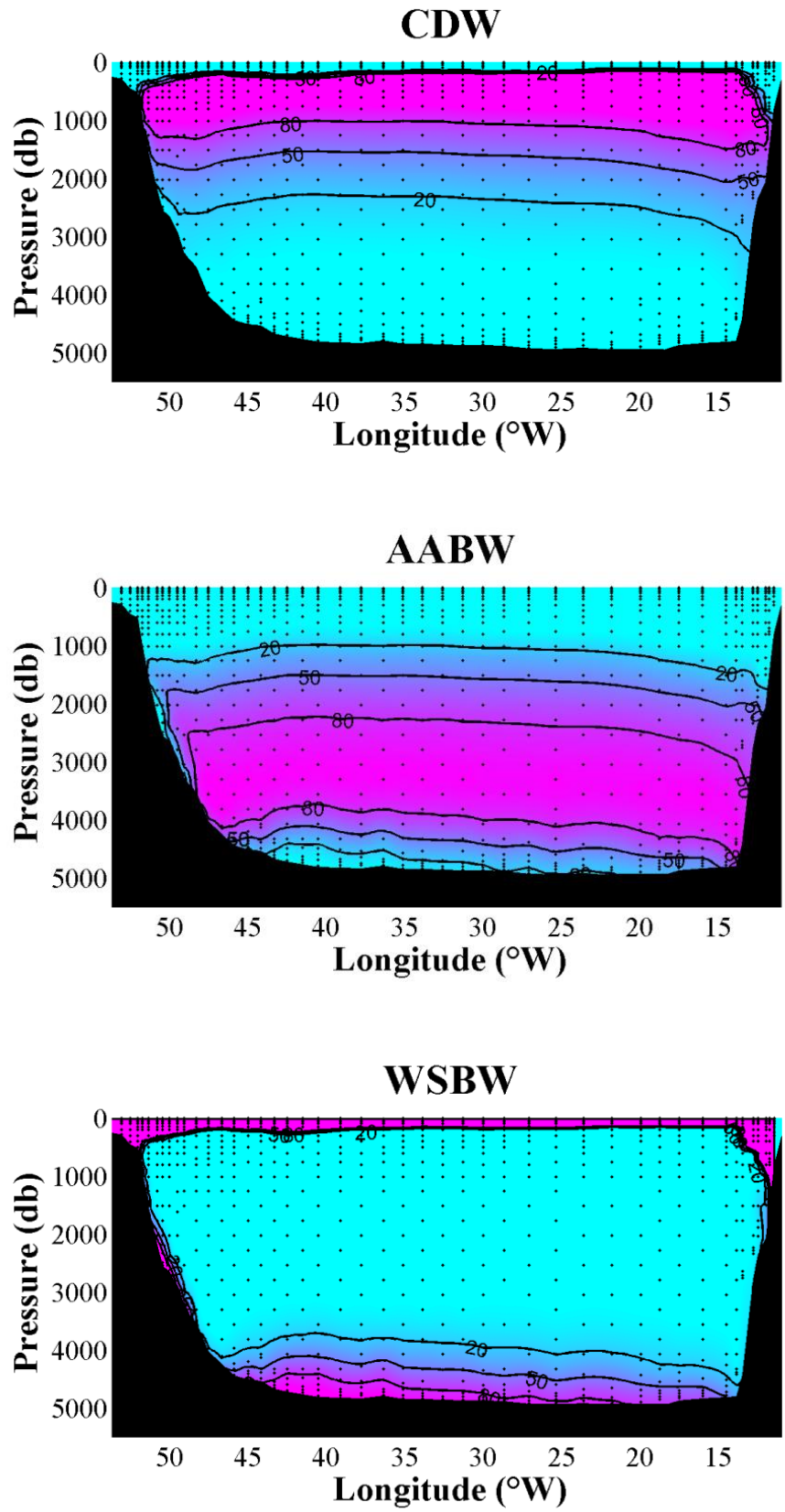

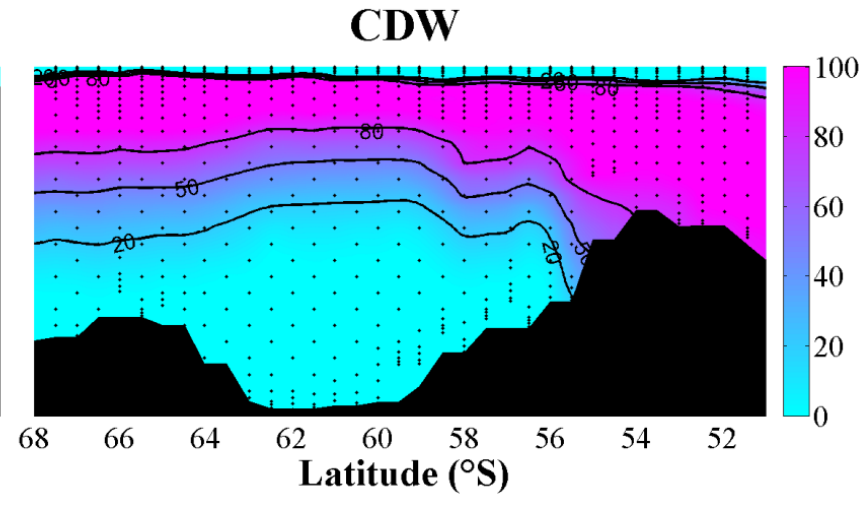

AABW

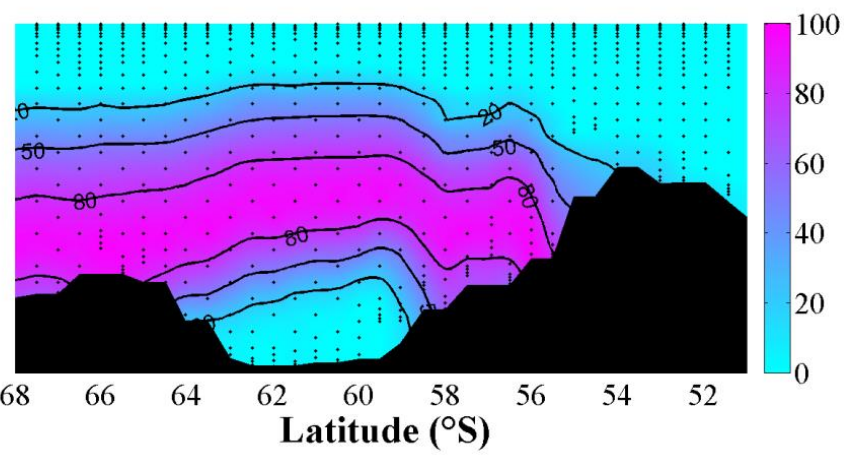

WSBW

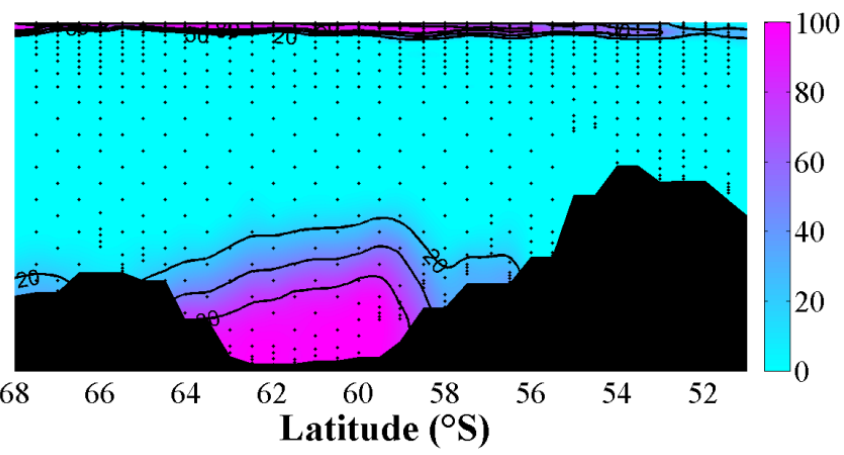

Fig. 12 Distribution of Southern Water Masses (CDW, AABW and WSBW) based on SR04 cruises

Left figures show the west (zonal) part and right figures show the east (meridional) part

Contour lines show fractions of $20 \% 50 \%$ and $\mathbf{8 0} \%$, blue lines show cross section of other cruises 
Ocean Sci. Discuss., https://doi.org/10.5194/os-2018-140

Manuscript under review for journal Ocean Sci.

Discussion started: 17 January 2019

(C) Author(s) 2019. CC BY 4.0 License.

$40^{\circ} \mathrm{N}$

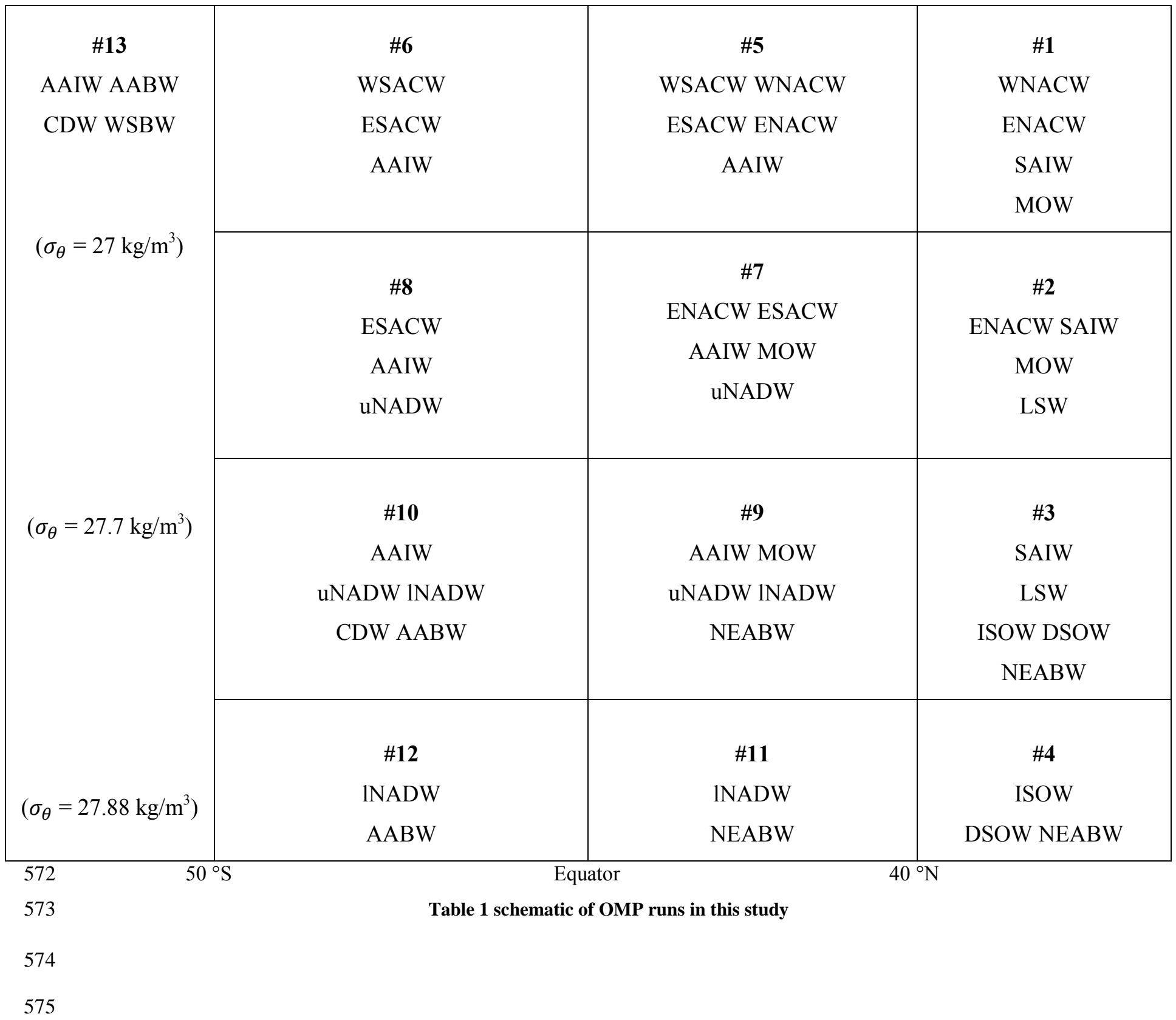

